\title{
Investigating the Effects of Self-Esteem on Attachment Styles in Individuals in Early Adulthood: The Mediating Roles of Emotional Dependency and Loneliness*
}

Abdi GÜNGÖR**

\author{
Kübra KABA ${ }^{* * *}$
}

\begin{abstract}
Investigating the concepts affecting individuals' attachment styles in early adulthood is essential for healthy and satisfying social and emotional/romantic relationships. The purpose of this study was to examine the direct effects of selfesteem, loneliness, and emotional dependency on university students' attachment styles. In addition, this study investigated the mediating roles of emotional dependency and loneliness on the relationships between attachment styles and selfesteem. The research group consisted of 518 volunteer university students in their first adulthood. Demographic Information Form, Rosenberg Self- Esteem Scale (RSES), Experiences in Close Relationships- Revised (ECR- R), Emotional Dependency, and UCLA Loneliness Scale were used to collect the data. Pearson moments correlation coefficients, hierarchical regression analyses, and bootstrapping methods were performed to test the hypotheses. The results of hierarchical regression analysis showed that self-esteem negatively and loneliness positively predicted anxious and avoidant attachment styles. Emotional dependency positively predicted anxious attachment and negatively predicted avoidant attachment styles. In addition, the bootstrapping analysis showed that loneliness played a significant partial mediator role on the relationships between self-esteem and avoidant and anxious attachment, while emotional dependency was not a significant mediator. The findings were discussed along with the theoretical basis and the previous findings, and suggestions were presented for future studies.
\end{abstract}

Keywords: Attachment styles, self-esteem, loneliness, emotional dependency, mediation.

\footnotetext{
* Ethics committee approval for this study was obtained from Düzce University Scientific Research and Publication Ethics Committee with the decision dated 25/06/2021 and numbered 2020/132.

*** Orcid ID: https://orcid.org/0000-0002-7945-0906, Assist. Prof. Dr., Düzce University, Turkey, abdigungor@duzce.edu.tr

*** Orcid ID: https://orcid.org/0000-0002-4644-0963, Turkey, kubraakabaa.96@gmail.com
} 


\section{INTRODUCTION}

Although different theorists have studied the early adulthood period in different age ranges, Erikson defined this period as the isolation against intimacy, covering the age range of 20-40. One of the primary developmental tasks of individuals in this period is to establish healthy and satisfying social and emotional close relationships (Erikson, 1968). If individuals cannot establish intimacy and have intimate relationships, they cannot be emotionally satisfied, and consequently, their relationships remain superficial. If people realize that their relationships are not deep enough, they isolate themselves from the relationships and cannot healthily go through this period (Burger, 2006; Havighurst, 1972; Levinson, 1986). Attachment styles play an important role in the successful fulfillment of establishing healthy emotional and romantic relationships, which are the main developmental tasks of individuals in their first adulthood.

The concept of attachment was first proposed through Bowlby's work on babies (Bowlby, 1973, 1980), and Ainsworth's also expanded attachment into adults' emotional and social relationships (Ainsworth, 1967). Bowlby defined the concept of attachment as the emotional attachment the baby developed towards the caregiver. (Bowlby, 1973). Although there are different classification of attachment styles in the literature (Bartholomew \& Horowitz, 1991; Hazan \& Shaver, 1987), Ainsworth and his colleagues examined the patterns of mother's behavior, the effect of attachment styles between mother and baby. They conceptualized attachment styles in three categories (Ainsworth, Bleahi, Waters \& Wall, 1978). These categories are secure, anxious/ambivalent, and anxious/avoidant attachment. Consistent with the classification of Ainsworth et al., Hazan and Shaver (1987) also defined three types of attachment for adults: secure, anxious-ambivalent, and avoidant attachment. People with secure attachments are more comfortable communicating with people and do not abandon or feel uncomfortable when they are too close to someone. Individuals with an avoidant attachment style, on the other hand, have difficulty in trusting and being close to others in relationships. Intimacy makes them uncomfortable. Unlike individuals with avoidant attachment, people with anxious-ambivalent attachment constantly desire to establish closeness and have thoughts that their partners do not have the same feelings (Hazan \& Shaver, 1987).

The literature has revealed the relationships between attachment styles and many variables. For example, the secure attachment was found to be positively related to perceived satisfaction in the relationships (Sümer, 2006), marital adjustment (Senchak \& Leonard, 1992), relational self-esteem (Hamarta, 2004), hope and trust (Simmons, Gooty, Nelson, \& Little, 2009), and protective health behavior (Huntsinger \& Luecken, 2004). On the other hand, the anxious attachment and avoiding attachment were positively related to relationship satisfaction (Sarl \& Owen, 2016), sexual satisfaction (Butzer \& Campbell, 2008), agreement and relationship dimensions of the marital adjustment (Karabacak Çelik \& Çitfci, 2020), marital satisfaction (Sarı, 2012), selfesteem (Huntsinger \& Luecken, 2004; Famously, 2015); and positively related to depression (Karlıoğlu and Parlar, 2020), predisposition to depressive symptoms (Scott \& Cordova, 2002) and negative conflict resolution skills and cheating tendency 
(Kantarcl, 2009). As widely discussed in the literature, attachment styles are important in individuals' social and emotional/romantic relationships. Anxious and avoidant attachment styles can be a risk factor for individuals' emotional and social relationships and quality of life.

Previous studies also showed the importance of attachment styles for college students. Studies conducted with university students showed that the anxious and avoidant attachment styles were negatively associated with life satisfaction (Odacl, Cıkrıkcl, Clkrıkcl, \& Aydin, 2019; Tepeli Temiz \& Tari Comert, 2018), sociability (Arfaei \& Najaryan, 2016), and marital satisfaction (Hamidi, 2007). On the other hand, positive relationships were found between the anxious and avoidant attachment styles and loneliness (Wiseman, Mayseless, \& Sharabany, 2006), suicidal ideation (Taklavi \& Ghodrati, 2019), and depression (Ahmadi, Daneshvarpoor \& Karimi, 2011). It is an important developmental task for university students to have healthy relationships. In this context, it will be helpful to investigate the factors related to attachment styles in the sample of individuals in their first adulthood period for developing educational and psychological support for them. This study examined the effects of self-esteem, loneliness, and emotional dependency on attachment styles in people in the first adulthood period.

\section{Self Esteem}

Rosenberg (1965) defined self-esteem as positive and negative perceptions of the person towards himself or herself. Rogers (1959) addressed self-esteem within the context of the attachment between the baby and the caregiver. According to Rogers, the perception of people with high self-esteem towards themselves is positive, while this perception is more negative in people with low self-esteem. As Rogers points out, because self-perception is related to the attachment between the baby and the caregiver, theoretically speaking, individuals' perceptions of themselves may also impact the attachment styles in their social or emotional/romantic relationships.

The literature showed that self-esteem was positively related to dyadic adjustment (Turanlı, 2010), relationship satisfaction (Kırıt Gülaydın \& Semerci, 2018), emotional intelligence (Bibi, Saqlain, \& Mussawar, 2016), academic performance (Arshad, Zaidi, \& Mahmood, 2015; Saadat, Ghasemzadeh, \& Soleimani, 2012), optimism and happiness (Dar \& Wani, 2017), life satisfaction (Arslan, Hamarta, \& Uslu, 2010) and secure attachment (Terzi \& Çankaya, 2009); while negatively associated with stress and depression (Ha, 2010), anxiety (Mustafa, Melonashi, Shkembi, Besimi, \& Fanaj, 2015), internet addiction (Bahrainian, Alizadeh, Raeisoon, Gorji, \& Khazaee, 2014), and loneliness (Ahadi, 2009). There are also studies that investigated the relationships between self-esteem and attachment styles. Negative relationships were found between self-esteem and insecure attachment styles (Çeçen, 2017; Dhal, Bhatia, Sharma, \& Gupta, 2007; Tepeli Temiz, 2017; Turanl,, 2010; Ünlü, 2015). Both theoretically and empirically, a negative relationship is expected between self-esteem and anxious and avoidant attachment styles. 
However, there may be variables that mediate the relations between these relationships. A mediator variable describes how there is a relationship between two or more variables. (Preacher \& Hayes, 2004, 2008). In other words, the mediator variable explains through which variable(s) an independent variable affects a dependent variable, revealing the factors that play a central role in the prediction of the dependent variable. This study examined the mediator roles of loneliness and emotional dependency in the relationships between self-esteem and attachment styles. The hypotheses regarding the potential mediator effects of loneliness and emotional dependency are explained based on theoretical and empirical findings in the literature.

\section{Loneliness}

According to Erikson, loneliness occurs because of one's inability to establish close relationships and complete their identity development (as cited in Burger, 2006). According to Weiss (1973), loneliness is experienced resulting from the absence of one or more conditions: attachment, social relations, relationships including altruism, appraisal of the individual's characteristics, social support system, and guidance. Loneliness is a psychological condition rather than a physical condition. It arises from the difference between the social network the individuals interact with and the idealized social network they want to have. Individuals who feel lonely are not in harmony with their environment, they experience superficial relationships rather than deep and meaningful relationships, and their egocentric thoughts are quite high (Ünlü, 2015).

Loneliness was found to be negatively related to self-esteem and resilience (Güloğlu \& Karaırmak, 2010; Karababa, 2021), social support (Avcı \& Yıldırım, 2014), secure attachment (Bernardon, Babb, Hakim Larson, \& Gragg, 2011), emotional contagion (Borawski, Wajs, Sojka \& Misztal, 2020), marital quality (Isanejad \& Bagheri, 2018), and academic performance (Stoliker \& Lafreniere, 2015). On the other hand, the literature revealed that loneliness was positiviely associated with violence tendency (Avcı \& Ylldırım, 2014), isolation and powerlessness, which are sub-dimensions of alienation (Atli, Keldal, \& Sonar, 2015), anxious and avoidant attachment (Suri, Garg, \& Tholia, 2019) and online cheating ( Isanejad \& Bagheri, 2018).

\section{Emotional Dependency}

Emotional dependency occurs when the individual needs to be emotionally attached and has been considered a condition characterized by insecure attachment and low selfesteem (Arntz, 2006; Scantamburlo, Pitchot \& Anseau, 2013). Individuals with high emotional dependency have an intense sense of loneliness and emptiness and constantly desire to establish a relationship with others. Those individuals have an intense belief of abandonment in their relationships with spouses or social circles (Arntz, 2006). They also lack the belief that they can provide their own emotional security and stable mood, and they need someone else to provide them. Because they do not believe that they can cope with the feeling of emptiness, they always seek support. This sense of emptiness is an intense situation for them, and they do not perceive the ability to cope with it since these people do not have a strong sense of identity (Hoogstad, 2008). 
Although there are limited studies on emotional dependency in the literature, previous studies showed that emotional dependency was found to be related to marital harmony and emotional addiction (Cirhinlioğlu, Kintap Tepe, \& Cirhinlioglu, 2017), relationship saturation (Kemer, Çetinkaya Yıldız, \& Bulgan, 2016), anxiety and depressive symptoms (Estévez, Urbiola, Iruarrizaga, Onaindia, \& Jauregui, 2017), and anxious attachment (Arbiol, Shaver \& Yarnoz, 2002). In addition, negative associations were found between emotional dependency and termination of the relationships in abused individuals (Bornstein, 2006) and self-esteem (Estévez et al., 2017).

\section{The Mediator Role of Loneliness and Emotional Dependency}

Theoretically speaking, individuals with low self-esteem are likely to experience problems in their relationships due to their negative self-perceptions (Burger, 2006; Weiss, 1973). In addition, there are studies in the literature supporting this (e.g., Atli et al., 2015; Avcı \& Yıldırım, 2014; Isanejad \& Bagheri, 2018). Studies show a positive relationship between loneliness and anxious and avoidant attachment (e.g., Bernardon et al., 2011; Suri et al., 2019). Negative self-perception prevents the person from establishing healthy relationships in his or her social and romantic relationships. Therefore, this leads to loneliness, which prevents the person from establishing deep relationships and staying superficial in their relationships (Rosenberg, 1965; Ünlü, 2015). In the case of loneliness, the attachment system becomes effective, consistent with the bond between the person and the caregiver. Thus, loneliness can lead the person to be more anxious or avoidant in his or her relationships because individuals with a secure attachment style are expected to deal with loneliness efficiently. As the loneliness increases, the insecure attachment styles of the person will also be escalated. Therefore, it is hypothesized that low self-esteem predicts high levels of loneliness, which in turn predicts high levels of the anxious and avoidant attachment style.

Regarding the mediating role of emotional dependency, self-esteem and insecure attachment are the basic concepts in defining emotional dependency (Arntz, 2006; Scantamburlo et al., 2013). Individuals with low self-esteem, who have negative perceptions about themselves, especially, believe that they cannot provide stability for their emotional states. Therefore, they are expected to feel an intense need for attachment to the other person in the relationship. At the same time, it is expected that emotional dependency, which is experienced as a need for intense attachment to the other person, would positively associate with an anxious attachment style, which refers to the need for intense feelings towards their partners. On the other hand, the emotional dependency would be negatively related to the avoidant attachment style, which refers to not wishing to establish close relationships and preference to be distant in their relationships. In this respect, individuals with low self-esteem are expected to have higher levels of emotional dependency, which in turn predicts higher levels of insecure attachment. Regarding the relationship between emotional dependency and attachment, it is expected that emotional dependency has a positive relationship with anxious attachment and a negative relationship with avoidant attachment. 
As a result, the university period mainly corresponds to the first adulthood period, and the primary developmental tasks of individuals in this period are to develop social and emotional relationships in which they can have a sense of intimacy (Erikson, 1968; Havighurst, 1972; Levinson, 1986). Not establishing healthy relationships in this period will cause a crisis (isolation) that will prevent establishing healthy relationships in later developmental ages and prepare the ground for the negativities that may occur in later in life. In this respect, it is important to investigate the factors that may affect attachment styles, which have an important effect on the relationships of university students. This study examined the predictive effect of self-esteem on anxious and avoidant attachment levels in a sample of university students. In addition, another purpose of this study was to examine the mediating roles of loneliness and emotional dependency on the relationships between self-esteem and attachment styles. Therefore, the central roles of loneliness and emotional dependency on attachment styles will be better understood. Results of this study will contribute to interventions and preventive efforts for individuals in ensuring a healthy relationship and communication process.

\section{METHOD}

\section{Study Group}

Ethics committee approval for this study was obtained from Düzce University Scientific Research and Publication Ethics Committee with the decision dated 25/06/2021 and numbered 2020/132. The participants included of university students aged of 18-35 ( $\bar{x}=$ 21.37; $N=2.39$ ). Participants consisted of 518 volunteers, 134 (25.87\%) men and 384 (74.13\%) women. Of the participants, 119 (22.97\%) were first graders, 111 (21.43\%) were second graders, 168 (32.43\%) were third graders, 68 were fourth graders (13.13\%), and 52 (\% 10.04) were graduate students.

\section{Measurements}

\section{Personal Information Form}

The personal information form created by the researchers was used to collect demographic information such as age, gender, and class level of the participants.

\section{UCLA Loneliness Scale}

The scale was developed by Russell, Peplau, and Ferguson (1978) to measure the loneliness levels of individuals and was adapted into Turkish by Demir (1989). The scale consists of a total of 20 items, and 10 of these items were reverse coded. The items are on a 4-point Likert scaling, ranging from 1 (I never live) to 4 (I live often). The total scores range between 20 and 80, and a higher score indicates a higher level of loneliness. Demir (1989) found the internal consistency coefficient as .94 regarding the reliability of the scale. In this study, the internal consistency coefficient was found to be .92 . 


\section{Experiences in Close Relationships-Revised}

It was developed by Fraley, Waller, and Brennan (2000) and adapted into Turkish by Selcuk, Günaydın, Sümer, and Uysal (2005). There are 36 items on a 7-point Likert type; 18 items measure the anxious attachment type, while the other 18 measure the avoidant attachment type. Scores for each dimension are obtained by summing the scores. Higher scores indicate higher levels of the relevant attachment type. The internal consistency coefficients were.90 for the avoidant dimension and .86 for the anxiety dimension (Selçuk et al., 2005). In this study, internal consistency coefficients were found to be .91 and 89 , respectively.

\section{Emotional Dependency Scale}

The scale was developed by Buunk (1981) and adapted into Turkish by Karakurt (2001). The scale consists of nine items on a 7-point Likert type; one item is reverse coded. A high score indicates a higher level of emotional dependency. Buunk (1981) reported the internal consistency coefficient as .81. In this study, the internal consistency coefficient was found to be 89 .

\section{Rosenberg Self-Esteem Scale (RSES)}

The RSES developed by Rosenberg (1965) is a self-evaluation scale. The adaptation of the scale into Turkish was made by Çuhadaroğlu (1986). The scale consists of 63 items on a 4-point Likert-type rating and 12 sub-dimensions. In this study, only the 10 -item self-esteem sub-dimension was used. Five items in the scale were reverse coded. The scores range between 10 and 40; higher scores indicated higher levels of self-esteem. Çuhadaroğlu (1986) reported the reliability coefficient as .75. In this study, the internal consistency coefficient was found to be .87 .

\section{Process}

Before proceeding to the data collection process, required ethical and administrative permissions were obtained. The data were collected via a link in an online platform. Before the participants started answering the questionnaire, the purpose, importance, and scope of the research were explained. In addition, the participants were asked a yes/no question whether they volunteered to participate in the research, and confidentiality was emphasized. The data were analyzed using the SPSS 22.00 package program, and the interpretation of the findings was based on the .05 significance level.

Two steps were followed in the analyses of the data. First, the suitability of the data for the multivariate analyses was tested. Then, the prediction of the independent variables on the dependent variables was examined. In this context, two hierarchical regression analyses were conducted to investigate to what extent self-esteem, loneliness, and emotional dependency (independent variables) predicted the anxious attachment and avoidant attachment (dependent variables). In addition, parallel mediator analyses were conducted to test the mediating roles of loneliness and emotional dependency on the associations between self-esteem and attachment styles. A 10,000 iteration method was 
used by using bootstrapping with the SPPS-macro program to test the significance of the mediator effects (Preacher \& Hayes, 2004, 2008).

Outliers, multicollinearity between variables, variance inflation factor (VIF), and tolerance values were examined in the first step. Three outliers were detected by checking the Mahalanobis distance values and removed from the dataset. Kurtosis values were between .03 and .97, and skewness values varied between .24 and -1.06. Therefore, the dataset met the assumptions of normality (Pallant, 2010; Tabachnick \& Fidell, 2013). In terms of multicollinearity, VIF values were less than ten, and tolerance levels were greater than 10. Additionally, the correlations between the independent variables ranged from -.02 to -.48 . The results showed that there was no multicollinearity problem between the independent variables. Overall, the data met the required assumptions for multivariate analyses.

\section{FINDINGS}

The correlations between dependent and independent variables and descriptive statistics about the variables are shown in Table 1. According to the Pearson ProductMoment Correlation Coefficients, anxious attachment was negatively correlated with self-esteem $(r=-.49, p<.01)$, and positively correlated with loneliness $(r=.42, p<.01)$ and emotional dependency $(r=.12, p<.01)$. Avoidant attachment was negatively correlated with self-esteem $(r=-.39, p<.01)$ and emotional dependency $(r=-.27, p<$ $.01)$, and positively correlated with loneliness $(r=.39, p<.01)$.

Table 1.

The Relationships Between Anxious Attachment, Avoidant Attachment, Self-Esteem, Loneliness, and Emotional Dependency and Descriptive Statistics

\begin{tabular}{lccccc}
\hline Variables & 1 & 2 & 3 & 4 & 5 \\
\hline Anxious Attachment & 1 & & & & \\
Avoidant Attachment & $.39^{* *}$ & 1 & & & \\
Self Esteem & $-.49^{* *}$ & $-.39^{* *}$ & 1 & & \\
Loneliness & $.42^{* *}$ & $.39^{* *}$ & $-.48^{* *}$ & 1 & \\
Emotional Dependency & $.12^{* *}$ & $-.27^{* *}$ & -.02 & $.09^{*}$ & 1 \\
$\bar{X}$ & 60.69 & 54.82 & 30.70 & 33.71 & 32.74 \\
$S S$ & 17.93 & 18.81 & 4.95 & 10.16 & 11.84 \\
\hline$* p<.05, * * p<.01$ & & & & &
\end{tabular}




\section{Prediction of Avoidant Attachment Scores}

A two-step hierarchical regression analysis was conducted to test the predictors of selfesteem, loneliness, and emotional dependency scores on avoidant attachment scores (Table 2). In the first stage, the predictor of self-esteem on avoidant attachment was tested. Results showed that self-esteem negatively predicted avoidant attachment and explained $16 \%$ of the variance. In the second step, loneliness and emotional dependency were added to the model and explained an additional $14 \%$ of the variance. All the independent variables together explained $30 \%$ of the total variance. In the second step, when loneliness and emotional dependency were added to the model, the effect of selfesteem decreased from $\beta=-.39$ to $\beta=-.26$. This result showed the possible mediating effects of loneliness and emotional dependency, but further analysis is required to determine the level of this effect.

Table 2.

Results of Hierarchical Regression Analysis on Predicting Avoidant Attachment Style

\begin{tabular}{|c|c|c|c|c|c|c|c|c|}
\hline Variables & $R^{2}$ & $\Delta R^{2}$ & $B$ & $\begin{array}{c}\text { Standard } \\
\text { Error }\end{array}$ & $B$ & $T$ & $P$ & $F$ \\
\hline Step 1 & .16 & & & & & & & $96.69^{* * *}$ \\
\hline Self Esteem & & & -1.51 & .15 & -.39 & -9.83 & .000 & \\
\hline Step 2 & .30 & $.14^{* * *}$ & & & & & & $74.21^{* * *}$ \\
\hline Self Esteem & & & -.99 & .16 & -.26 & -6.16 & .000 & \\
\hline Loneliness & & & .55 & .08 & .29 & 7.01 & .000 & \\
\hline $\begin{array}{l}\text { Emotional } \\
\text { Dependency }\end{array}$ & & & -.49 & .06 & -.31 & -8.25 & .000 & \\
\hline
\end{tabular}

$* * * p<.001$

\section{Prediction of Anxious Attachment Scores}

Another two-step hierarchical regression analysis was performed to test the independent variables' prediction of anxious-attachment scores (Table 3). In the first step, self-esteem significantly predicted anxious attachment and explained $24 \%$ of the variance. In the second step, loneliness and emotional dependency were added to the model and explained an additional $5 \%$ of the variance. All independent variables together explained $29 \%$ of the total variance. In the second step, when loneliness and emotional dependency were added to the model, the effect of self-esteem decreased from $\beta=-.49$ to $\beta=-.38$. This result showed the potential mediating effects of loneliness 
and emotional dependency on the association between self-esteem and anxious attachment, but further analysis is required to determine the level of this effect.

Table 3.

Results of Hierarchical Regression Analysis on the Prediction of Anxious Attachment Style

\begin{tabular}{|c|c|c|c|c|c|c|c|c|}
\hline Variables & $R^{2}$ & $\Delta R^{2}$ & $B$ & $\begin{array}{c}\text { Standard } \\
\text { Error }\end{array}$ & $B$ & $T$ & $P$ & $F$ \\
\hline Step 1 & .24 & & & & & & & $1665.92^{* * *}$ \\
\hline Self Esteem & & & -1.79 & .14 & -.49 & -12.88 & .000 & \\
\hline Step 2 & .29 & $.05^{* * *}$ & & & & & & $72.34^{* * *}$ \\
\hline Self Esteem & & & -1.37 & .15 & -.38 & -8.98 & .000 & \\
\hline Loneliness & & & .41 & .08 & .23 & 5.46 & .000 & \\
\hline $\begin{array}{l}\text { Emotional } \\
\text { Dependency }\end{array}$ & & & .14 & .06 & .09 & 2.49 & .013 & \\
\hline
\end{tabular}

${ }^{* * *} p<.001$

\section{Findings Regarding the Mediating Effects of Loneliness and Emotional Dependency}

Three conditions are required for testing a mediating variable. First, the independent variable must predict the mediator variable, and second, the independent variables must predict the dependent variable. Third, when the mediating variable is added to the model, the effect of the independent variable should disappear or decrease (Baron and Kenny. 1986). According to the hierarchical regression results, the second and third conditions were already met when predicting avoidant and anxious attachment.

Figure 1 showed the results of the resampling method on the mediating effects of loneliness and emotional dependency on the relationship between self-esteem and avoidant attachment. The direct and total effects are shown from self-esteem to loneliness and emotional dependency, from loneliness and emotional dependency to avoidant attachment, and from self-esteem to avoidant attachment in the figure. The effect of loneliness on self-esteem was significant, and 95\% bias-corrected confidence intervals did not include the zero value when predicting avoidant attachment through loneliness [range of -.73 and -.38]. The effect from self-esteem to emotional dependency was not significant. Therefore, the mediator role of emotional dependency did not meet the conditions, and 95\% bias-corrected confidence intervals included zero when predicting avoidant attachment through emotional dependency [range of -.09 and .13]. Additionally, the direct effect of self-esteem on avoidant attachment was still significant. 
Therefore, while loneliness partially mediated self-esteem and avoidant attachment, emotional dependency was not a significant mediator.

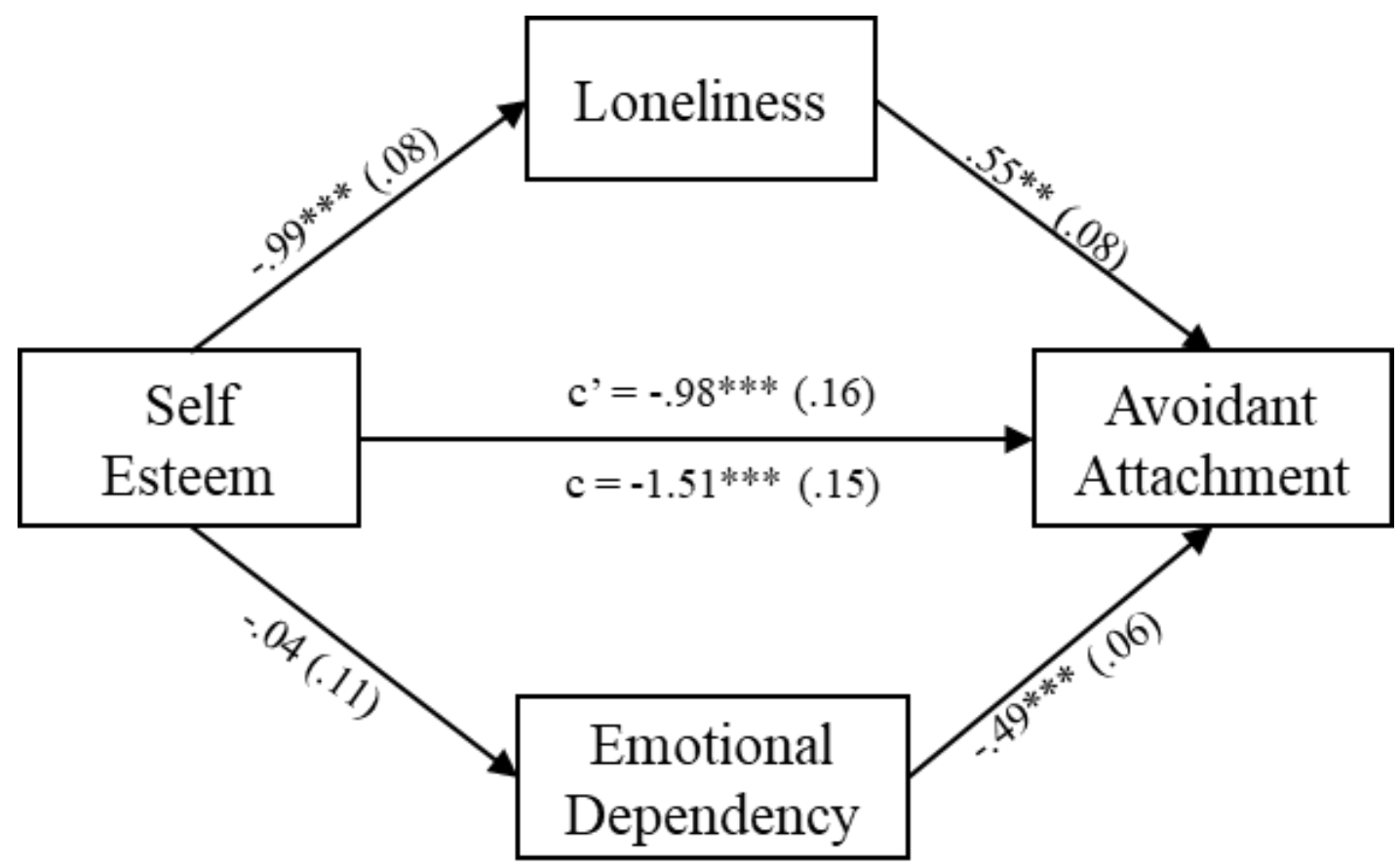

Figure 1. The Mediating Role of Loneliness and Emotional Dependency on the Relationship Between Self-Esteem and Avoidant Attachment. All effects are nonstandardized values, and standard errors are shown in parentheses. The value $c^{\prime}$ value represents the direct effect on avoidant attachment; the $\mathrm{c}$ value represents the total effect of self-esteem on avoidant attachment.

The results related to mediating roles of loneliness and emotional dependency on the association between self-esteem and anxious attachment are shown in Figure 2. The direct effect of self-esteem on loneliness was significant, and 95\% bias-corrected confidence intervals did not include zero when predicting avoidant attachment through loneliness [range of -.60 and -.24]. The direct effect of self-esteem on emotional dependency was not significant, so the mediator role of emotional dependency did not meet the conditions. In addition, 95\% bias-corrected confidence intervals included zero when predicting anxious attachment through emotional dependency [-.05 and 02 range]. However, the direct effect from self-esteem to anxious attachment was still significant. Thus, while loneliness partially mediated self-esteem and anxious attachment, emotional dependency was not a significant mediator. 


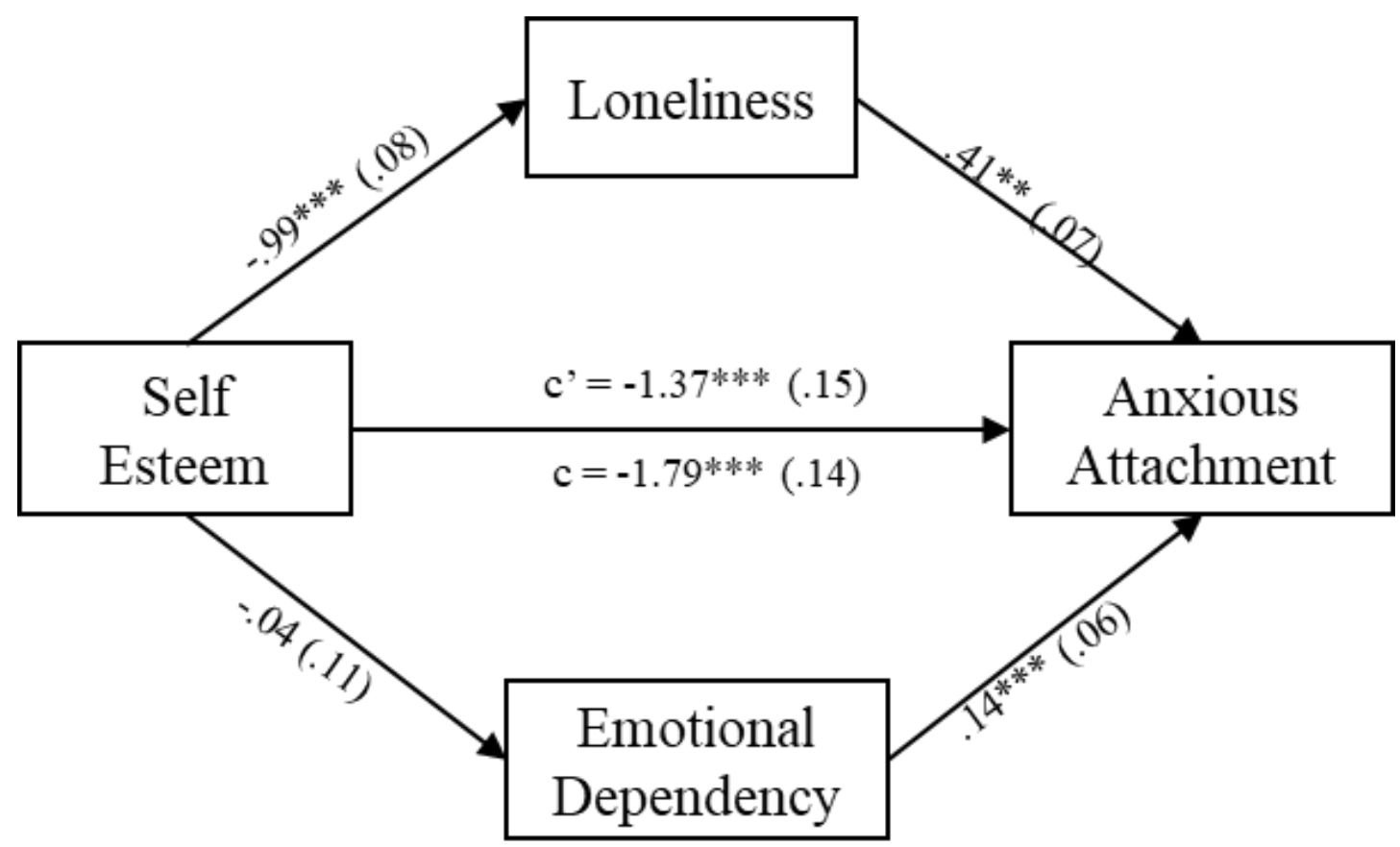

Figure 2. The Mediating Role of Loneliness and Emotional Dependency on the Relationship Between Self-Esteem and Anxious Attachment. All effects are nonstandardized values, and standard errors are shown in parentheses. The value $c^{\prime}$ value represents the direct effect on anxious attachment; the $c$ value represents the total effect of self-esteem on anxious attachment.

\section{RESULTS, DISCUSSIONS AND SUGGESTIONS}

One of the most important factors in establishing a healthy and intimate relationship in early adulthood is attachment style. There are differences in relationship and marital satisfaction, anxiety levels, irrational beliefs, depression, and many other factors based on securely or insecurely attached individuals. This study examined the relationships between individuals' self-esteem and attachment styles and the mediating roles of emotional dependency and loneliness on that relationship.

The findings showed that there was a negative relationship between self-esteem and avoidant and anxious attachment. According to Rosenberg (1965), self-esteem represents one's thoughts about himself. Individuals with an avoidant attachment style have difficulty establishing close contact with other people and have difficulty trusting. Individuals with an anxious attachment style have a fear of being abandoned by their partners (Hazan \& Shaver, 1987). Therefore, the theoretical base supports the negative relationships between self-esteem and anxious and avoidant attachment styles. The literature also supports these findings (Çeçen, 2017; Tepeli Temiz, 2017; Turanl, 2010). According to these results, as self-esteem decreases, the scores of the anxious and avoidant attachment styles increase. 
The other finding of the research was the positive relationships between loneliness and avoidant and anxious attachment styles. Loneliness occurs due to the person's inability to be in close relationships (Burger, 2006), which theoretically supports the findings. Thus, as one's loneliness scores increase, the avoidant and anxious attachment scores also increase. Previous findings are also consistent with these results (Suri et al., 2019; Wiseman et al., 2006).

The results revealed that emotional dependency was positively related to anxious attachment and negatively related to avoidant attachment. There was a positive and significant relationship between emotional dependency and anxious attachment and a significant negative relationship with avoidant attachment. Theoretically speaking, it was expected that the anxious attachment style was positively associated with emotional dependency because emotional dependency refers to the person's intense need for emotional attachment to another person (Arntz, 2006). In addition, people with avoidant attachment do not prefer close relationships (Hazan \& Shaver, 1987), so the negative association between emotional dependency and avoidant attachment was expected. The literature also supports these findings (Arbiol et al., 2002). As a result, these findings showed that as emotional dependency increases, the level of anxious attachment also increases, but avoidant attachment decreases.

In addition, this study examined the mediating role of loneliness and emotional dependency on the relationships between self-esteem and avoidant and anxious attachment styles. Loneliness played a mediating role between self-esteem and avoidant and anxious attachment. Therefore, as the self-esteem of the person decreases, the level of loneliness increases. Depending on the increase in the level of loneliness, there was an increase in the anxious and avoidant attachment style. In this sense, the partial mediating role of loneliness emphasizes its central role in predicting anxious and avoidant attachment styles. However, the significant direct effect of self-esteem should also be considered.

Emotional dependency was not significant a mediator between self-esteem and avoidant and anxious attachment. As hierarchical regression findings showed, emotional dependency positively predicted anxious attachment and negatively predicted avoidant attachment. However, self-esteem did not significantly predict emotional dependency. Therefore, different factors may affect the person's perceptions of self on the need to establish an intense relationship with his or her partner. Emotional dependency does not differ for individuals with positive self-esteem or individuals with negative selfesteem. More research is needed on this subject.

At this point, activities and interventions to increase a person's self-esteem may effectively reduce the anxious and avoidant attachment styles, which are defined as insecure attachment styles. Counseling practices with individuals and groups to increase one's self-esteem may be beneficial. Psycho-educational programs can also be effective. In addition, academic, social, and cultural interventions for university students can also increase their self-esteem, hence having more secure attachment styles in their 
relationships. Thus, the activities to make the person realize one's value can effectively change towards a more secure attachment style.

Considering the significant mediator role of loneliness, reducing individuals' loneliness can also contribute to a more secure attachment style. To cope with loneliness, activating a social support system, supporting self-confidence by enhancing positive features, and encouraging social relations can be helpful. In this sense, social and cultural activities and opportunities, individual or group interventions, and support services will be beneficial for individuals to cope with the feeling of loneliness. In addition, it will be helpful to screen university students' loneliness levels and develop preventive and intervention services. Thus, individuals' ability to cope with loneliness and their orientation towards a secure attachment style will contribute developing of satisfying relationships.

However, there are some limitations of this study. The research model was correlational, so it was not possible to make a definite cause-and-effect relationship. Nevertheless, the predictive findings were discussed from a theoretical point of view. Therefore, future studies can be conducted in experimental or longitudinal design to make a causal conclusion. There was also an imbalance between the number of female and male participants. Future studies can be conducted with a more balanced gender sample.

\section{References}

Ahadi, B. (2009). Relationship between loneliness and self- esteem with students' attachment styles. Quarterly Journal of Psychological Studies, 5(1), 95-112. doi: 10.22051/PSY.2009.1593

Ahmadi, T. S. M., Daneshvarpoor, Z., \& Karimi, L. (2011). The relationship between attachment styles and depression in university students. Journal of Sabzevar University of Medical Sciences, 18(3), 217-223.

Ainsworth, M. D. S., Blehai, M. C., Waters, E., \& Wall, S. (1978). Patterns of attachment: A psychological study of the strange situation. Hillsdale, NJ: Erlbaum.

Ainsworth, M.D.S. (1967). Infancy in uganda: Infant care and the growth of love. Baltimore: John Hopkins University Press. 
Arbiol, I. A., Shaver, P. R., \& Yarnoz, S. (2002). Insecure attachment, gender roles, and interpersonal dependency in Basque Country. Personal Relationship, 9(4), 479-490. doi: $10.1111 / 1475-6811.00030$

Arfaei, F. S., \& Najaryan, Z. (2016). The Relationship among attachment styles \& sssertiveness among University Students. Rooyesh, 4(4), 35-48.

Arntz, A. (2006). Dependency: Distinguishing functional from emotional dependency. Clinical Psychology: Science and Practice, 12(4), 411-416.

Arshad, M., Zaidi, S., \& Mahmood, K. (2015). Self esteem \& academic performance among university students. Journal of Education and Practice, 6(1), 156-162.

Arslan, C., Hamarta, E., \& Uslu, M. (2010). The relationship between conflict communication, self esteem and life satisfaction in university students. Educational Research and Reviews, 5(1), 31-34.

Atli, A., Keldal, G., \& Sonar, O. (2015). Üniversite öğrencilerinin yabancılaşma ve yalnızlık düzeyleri arasındaki ilişki [The relationship between alienation and loneliness levels of university students]. Mustafa Kemal Üniversitesi Sosyal Bilimler Enstitüsü Dergisi, 12(29), 149-160.

Avcı, Ö. H., \& Yıldırım, İ. (2014). Ergenlerde şiddet eğilimi, yalnızlık ve sosyal destek [Tendency to violence, loneliness and social support in adolescents]. Hacettepe Üniversitesi Eğitim Fakültesi Dergisi, 29(1), 157-168.

Bahrainian, S. A., Alızadeh, K. H., Raeisoon, M. R., Gorji, O. H., \& Khazaee, A. (2014). Relationship of internet addiction with self-esteem and depression in university students. Journal of preventive medicine and hygiene, 55(3), 86-89.

Baron, R. M., \& Kenny, D. A. (1986). The moderator-mediator variable distinction in social psychological research: Conceptual, strategic, andstatistical considerations. Journal of Personality and Social Psychology, 51(6), 1173-1182.

Bartholomew, K., \& Horowitz, L. (1991). Attachment styles among young adults: A test of a four category model. Journal of Personality and Social Psychology, 61, 226-244.

Bernardon, S., Babb, K. A., Hakim-Larson, J., \& Gragg, M. (2011). Loneliness, attachment, and the perception and use of social support in university students. Canadian Journal of Behavioural Science / Revue canadienne des sciences du comportement, 43(1), 4051. doi: $10.1037 / \mathrm{a} 0021199$

Bibi, S., Saqlain, S., \& Mussawar, B. (2016). Relationship between emotinal intelligence and self esteem among Pakistani university students. Journal of Psychology \& Psychotherapy, 6(4), 1-6. doi: 10.4172/2161-0487.1000279

Borawski, D., Wajs, T., Sojka, K., \& Misztal, U. (2020). Interrelations between attachment styles, emotinal contagion and loneliness. Journal of Family Issues. doi: $\underline{10.1177 / 0192513 X 20966013}$

Bornstein, R. F. (2006). The complex relationship between dependency and domestic violence: Converging psychological factors and social forces. American Psychologist, 61(6), 595-606. doi: 10.1037/0003-066X.61.6.595.

Bowlby, J. (1973). Attachment and loss. Separation, anxiety and anger. New York: Basic Books. 
Bowlby, J. (1980). Attachment and Loss, vol. 3: Loss-Sadness and Depression. New York: Basic Books.

Burger, J. M. (2006). Kişilik: Psikoloji biliminin insan doğasına dair söyledikleri. İstanbul: Kaknüs Yayınları.

Butzer, B., \& Campbell, L. (2008). Adult attachment, sexual satisfaction, and relationship satisfaction: A study of married couples. Personal Relationships, 15(1), 141154. doi:10.1111/j.1475-6811.2007.00189.x.

Buunk, B. (1981). Jealousy in sexually open marriages. Alternative Lifestyle, 4(3), 357-372. doi: $10.1007 / B F 01257944$

Cirhinlioğlu, F. G., Kindap Tepe, Y., \& Cirhinlioğlu, Z. (2017). Psychological distress, self esteem and emotional dependency of married individuals as predictors of marital adjustment. Procedia Computer Science, 120(2017), 164-171. doi: 10.1016/j.procs.2017.11.224

Çeçen, D. (2017). Yetişkinlerde Bağlanma stilleri ile benlik saygısı ve sürekli kaygı düzeyi arasindaki ilişkinin incelenmesi [Examining the relationship between attachment styles, self-esteem and trait anxiety levels in adults]. (Unpublished Masters' Thesis). Haliç University, İstanbul.

Çuhadaroğlu, F. (1986). Adolesanda benlik saygısı [Self-esteem in adolescence] (Unpublished Masters' Thesis). Hacettepe University, Ankara.

Dar, A. A., \& Wani, M. A. (2017). Optimisim, happiness and self- esteem among university students. Indian Journal of Positive Psychology, 8(3), 275-279.

Demir, A. (1989). U.C.L.A. Yalnızlık ölçeğinin geçerlik ve güvenirliği [U.C.L.A. the validity and reliability of the loneliness scale]. Psikoloji Dergisi, 7(28), 14-18.

Dhal, A., Bhatia, S., Sharma, V., \& Gupta, P. (2007). Adolescent self-esteem, attachment and loneliness. Journal of Indian Association for Child and Adolescent Mental Health, 3, 6163.

Erikson, H. E. (1968). Identity, youth and crisis. W. W. Norton Company.

Estévez, A., Urbiola, I., Iruarrizaga, I., Onaindia, J., \& Jauregui, P. (2017). Emotional dependency in dating relationships and psychological consequences of internet and mobile abuse. Anales de Psicología, 33(2), 260-268. doi: 10.6018/analesps.33.2.25511

Fraley, R. C., Waller, N. G., \& Brennan, K. A. (2000). An item response theory analysis of selfreport measures of adult attachment. Journal of Personality and Social Psychology, 78, 350-365. doi: 10.1037/0022-3514.78.2.350

Güloğlu, B., \& Karaırmak, Ö. (2010) Üniversite öğrencilerinde yalnızlığın yordayıcısı olarak benlik saygısı ve psikolojik sağlamlı [Self-esteem and psychological resilience as a predictor of loneliness in university students]. Ege Eğitim Dergisi, 11(2), 73-88.

Ha, J.Y. (2010). Drinking problems, stress, depression and self- esteem of university students. Korean Journal of Adult Nursing, 22(2), 182-189.

Hamarta, E. (2004). Üniversite Öğrencilerinin Yakın İlişkilerindeki Bazı Değişkenlerin (Benlik Saygısı, Depresyon ve Saplantılı Düşünme) Bağlanma Stilleri Açısından İncelenmesi [An Investigation of Some Variables (Self-Esteem, Depression, and Preoccupied Thinking) in 
Close Relationships of University Students in Terms of Attachment Styles]. (Unpublished Doctoral Dissertation). Selçuk University, Konya.

Hamidi, F. (2007). A study on the relationship between attachment styles and marital satisfaction in married students of teacher training university. Journal of familiy research, 3(9), 443-453.

Havighurst, R. J. (1972). Developmental tasks and education. David Mckay.

Hazan, C., \& Shaver, P. (1987). Romantic love conceptualized as an attachment process. Journal of Personality and Social Psychology, 52, 511-524. doi: 10.1037/00223514.52.3.511

Hoogstad, J. (2008). Choice theory and emotional dependency. International Journal of Reality Therapy, 28(1), 63-68.

Huntsinger, E. T., \& Luecken, L. J. (2004). Attachment relationships and health behavior: The mediational role of self-esteem. Psychology \& Health, 19(4), 515526. doi:10.1080/0887044042000196728

Isanejad, 0., \& Bagheri, A. (2018). Matiral quality, loneliness and internet infidelity. Cyberpsychology, Behavior and Social Networking, 21(9), 542-548. doi: 10.1089/cyber.2017.0602

Kantarcı, D. (2009). Evli bireylerin bağlanma stillerine göre aldatma eğilimleri ve çatışma yönetim biçimlerinin incelenmesi [Investigation of cheating tendencies and conflict management styles of married individuals according to their attachment styles.]. (Unpublished Masters' Thesis). İstanbul University, İstanbul.

Karababa, A. (2021). Understanding the association betweem parental attachment and loneliness among adolescents: The mediating role of self- esteem. Curr Psychol.doi: 10.1007/s12144-021-01417-z.

Karabacak Çelik, A., \& Çiftçi, M. (2020). Evli bireylerin bağlanma stilleri ve psikolojik iyi oluşlarının evlilik uyumlarını yordayıcı rolü. Uluslararası Türkçe Edebiyat Kültür Eğitim Dergisi, 9(2), 898-918.

Karakurt, G. (2001). Yetişkin bağlanma stillerinin romantik kıskançlık üzerindeki etkileri [Effects of adult attachment styles on romantic jealousy] (Unpublished Masters' Thesis). Orta Doğu Teknik University, Ankara.

Karlıoğlu, B., \& Parlar, H. (2020). Evli bireylerde bağlanma stillerinin depresyon üzerindeki etkisinin incelenmesi [Investigation of the effect of attachment styles on depression in married individuals]. Sosyal Bilimler Araştırma Dergisi, 9(3), 180-187.

Kemer, G., Çetinkaya Yıldız, E., \& Bulgan, G. (2016). Emotional dependency and dysfunctional relationship beliefs as predictors of married Turkish Individuals' relationship satisfaction. The Spanish Journal of Psychology, 19, 1-8. E72. doi:10.1017/sjp.2016.78.

Kırıt Gülaydın, G., \& Semerci, B. (2018). Romantik ilişkisi olan yetişkin bireylerin ilişki doyumlarının bağlanma stilleri, benlik saygısı ve kişilerarası ilişki tarzları açısından incelenmesi [Investigation of relationship satisfaction of adults with romantic relationships in terms of attachment styles, self-esteem and interpersonal relationship styles.]. Psikoloji Araştırmaları, 3(6), 14-25. 
Levinson, D. J. (1986). A conception of adult development. American Psychologist, 41(1), 313.

Mustafa, S., Melonashi, E., Shkembi, F., Besimi, K., \& Fanaj, N. (2015). Anxiety and self-esteem among university students: Comparison between Albania and Kosovo. Procedia Social and Behavioral Sciences, 205, 189-194.doi: 10.1016/j.sbspro.2015.09.057.

Odacı, H., Çıkrıkçı, Ö., Çıkrıkçı, N., \& Aydın, F. (2019). An exploration of the associations among cognitive flexibility, attachment styles and life satisfaction. International Journal of Happiness and Development, 5(3), 1-8. doi: 10.1504/IJHD.2019.103401.

Pallant, J. (2010). SPSS survival manual (4th ed.). New York, NY: McGrawHill.

Preacher, K. J., \& Hayes, A. F. (2004). SPSS and SAS procedures for estimating indirect effects in simple mediation models. Behavior Research Methods, Instruments, \& Computers, 36(4), 717-731. doi: 10.3758/BF03206553

Preacher, K. J., \& Hayes, A. F. (2008). Asymptotic and resampling strategies for assessing and comparing indirect effects in multiple mediator models. Behavior research methods, 40(3), 879-891. doi: 10.3758/BRM.40.3.879

Rogers, C. (1959). A theory of therapy, personality and interpersonal relationships as developed in the client-centered framework. In (ed.) S. Koch,Psychology: A Study of a Science. Vol. 3: Formulations of the Person and the Social Context. New York: McGraw Hill.

Rosenberg, M. (1965). Society and the adolescent self-image. Princeton, NJ: Princeton University Press.

Russell, D., Peplau, L. A., \& Ferguson, M. L. (1978). Developing a measure of loneliness. Journal of Personality Assessment, 42(3), 290-294. doi: 10.1207/s15327752jpa4203_11

Saadat, M., Ghasemzadeh, A., \& Soleimani, M. (2012). Self- esteem in Iranian university students and its relationship with academic achievement. Procedia- Social and Behavioral Sciences, 31, 10-14. doi:10.1016/j.sbspro.2011.12.007

Sarı, T. (2012). Evli bireylerin ebeveyn algıları, otomatik düşünceleri ve bağlanma stillerinin evlilik doyumu ile ilişkisi [The relationship between parental perceptions, automatic thoughts and attachment styles of married individuals and marital satisfaction]. (Unpublished Masters' Thesis). Haliç University, İstanbul.

Sarı, T., \& Korkut Owen, F. (2016). Romantik İlişkilerde akılcı olmayan inançların ve bağlanma boyutlarının ilişki doyumu üzerindeki yordayıcı rolünün incelenmesi [Examination of the predictive role of irrational beliefs and attachment dimensions on relationship satisfaction in romantic relationships]. Mehmet Akif Ersoy University Eğitim Fakültesi Dergisi, 1(37), 204-216.

Scantamburlo, G., Pitchot, W., \& Anseau, M. (2013). Affective dependency. Revue medicale de Liege, 68(5-6), 340-347.

Scott, R. L., \& Cordova, J. V. (2002). The influence of adult attachment styles on the association between marital adjustment and depressive symptoms. Journal of Family Psychology, 16(2), 199-208. doi: 10.1037/0893-3200.16.2.199. 
Selçuk, E., Günaydın, G., Sümer, N., \& Uysal, A. (2005). Yetişkin bağlanma boyutları için yeni bir ölçüm: Yakın ilişsilerde yaşantılar envanteri- II'nin Türk örnekleminde psikometrik açıdan değerlendirilmesi. Türk Psikoloji Yazıları, 8(16), 1-11.

Senchak, M., \& Leonard, K. E. (1992). Attachment styles and marital adjustment among newlywed couples. Journal of Social and Personal Relationships, 9(1), 51-64. doi: 10.1177/0265407592091003.

Simmons, B. L., Gooty, J., Nelson, D. L., \& Little, L. M. (2009). Secure attachment: Implications for hope, trust, burnout and performance. Journal of Organizational Behavior, 30(2), 233-247. doi: $10.1002 /$ job.585

Stoliker, B. E., \& Lafreniere, K. D. (2015). The influence of perceived stress, loneliness, and learning burnout on university students' educational experience. Collage Student Journal, 49(1), 146-160.

Suri, S., Garg, S., \& Tholia, G. (2019). Attachment style, perceived social support and loneliness among college students. International Journal of Innovative Studies in Sociology and Humanities (IJISSH), 4(5), 135-142.

Sümer, N. (2006). Yetişkin bağlanma ölçeklerinin kategoriler ve boyutlar düzeyinde karşılaştırılması [Comparison of adult attachment scales at the level of categories and dimensions]. Türk Psikoloji Dergisi, 21(57), 1-22.

Tabachnick, B., \& Fidell, L. (2013). Using multivariate statistics (6th ed.). Boston, MA: Pearson.

Taklavi, S., \& Ghodrati, S. (2019). Prediction of suicidal thoughts based on emotional failure and attachment styles among university students. Journal of Ardabil University of Medical Sciences, 19(2), 204-215.

Tepeli Temiz, Z. (2017). Üniversite öğrencilerinin bağlanma stilleri ile yaşam doyumu, psikolojik dayanıklık ve aleksitimik özellikleri arasındaki ilişkide benlik saygısının rolü [The role of self-esteem in the relationship between university students' attachment styles and their life satisfaction, resilience and alexithymic characteristics.]. (Unpublished Masters' Thesis). Fatih Sultan Mehmet University, İstanbul.

Tepeli Temiz, Z., \& Tarı Cömert, I. (2018). The relationship between life satisfaction, attachment styles, and psychological resilience in university students. Dusunen Adam The Journal of Psychiatry and Neurological Sciences, 31, 274-283. doi: 10.5350/DAJPN2018310305.

Terzi, Ş., \& Cihangir Çankaya, Z. (2009). The predictive power of attachment styles on subjective well being and coping with stress of university students. Türk Psikolojik Danışma ve Rehberlik Dergisi, 4(31), 1-11.

Turanlı, P. (2010). Orta yetişkinlikte evlilik uyumu ile benlik saygısı ve bağlanma stilleri arasındaki ilişkinin saptanması [Determining the relationship between marital adjustment, self-esteem and attachment styles in middle adulthood]. (Unpublished Masters' Thesis). Maltepe University, İstanbul.

Ünlü, F. (2015). Ebeveyni boşanmış bireylerde; benlik saygısı, yalnızlık ve bağlanma stilleri arasındaki ilişkinin incelenmesi [Examining the relationship between self-esteem, 
loneliness and attachment styles in individuals whose parents are divorced;]. (Unpublished Masters' Thesis). Haliç University, İstanbul.

Weiss, S. R. (1973). Loneliness: The experience of emotional and social isolation. New England: Typographical Service Inc.

Wiseman, H., Mayseless, O., \& Sharabany, R. (2006). Why are they lonely? Perceived quality of early relationships with parents, attachment, personality, predispositions and loneliness in first-year university students. Personality and Individual Differences, 40(2), 237-248. doi: 10.1016/j.paid.2005.05.015 
Ethics committee approval for this study was obtained from Düzce University Scientific Research and Publication Ethics Committee with the decision dated 25/06/2021 and numbered 2020/132.

Statement of Contribution of Researchers to the Article:

1st author contribution rate: $50 \%$

2nd author contribution rate: $50 \%$

Conflict of Interest Statement:

There is no conflict of interest.

Statement of Financial Support or Acknowledgment:

No financial support was received from any institution for this study. 


\title{
İlk Yetişkinlik Dönemindeki Bireylerde Bağlanma Stilleri Üzerinde Benlik Saygısının Etkisinin İncelenmesi: Duygusal Bağımlılığın ve Yalnızlığın Aracı Rolü*
}

\begin{abstract}
Abdi GÜNGÖR ${ }^{* *}$
Kübra KABA ${ }^{* * *}$

Öz. İlk yetişkinlik dönemindeki bireylerin bağlanma stillerini etkileyen kavramların araștırılması kişilerin sağlıklı ve doyum verici sosyal ve duygusal/romantik ilișkileri için önem arz etmektedir. Bu araştırmanın amacı ilk yetişkinlik dönemindeki üniversite öğrencilerinin bağlanma stilleri üzerinde benlik saygısı, yalnızlık ve duygusal bağımlılığın doğrudan etkilerinin incelenmesidir. Ayrıca bu araştırmada duygusal bağımlılığın ve yalnızlığın bağlanma stilleri ile benlik saygısı arasındaki ilişkilerdeki aracı rolü de incelenmiștir. Araștırma grubunu gönüllü 518 ilk yetişkinlik dönemindeki üniversite öğrencileri oluşturmaktadır. Araştırmada veriler Demografik Bilgi Formu, Rosenberg Benlik Saygısı Ölçeği, Yakın İlişkilerde Yaşantılar Envanteri II, Duygusal Bağımlılık Ölçeği ve UCLA Yalnızlık Ölçeği aracılı̆̆ı ile toplanmıştır. Araştırmadaki hipotezleri test etmek amacıyla Pearson momentler çarpım korelasyon katsayısı, hiyerarşik regresyon analizi ve yeniden örnekleme yöntemi (bootstrapping) yapılmıştır. Hiyerarşik regresyon analizi sonuçlarına göre benlik saygısı kaygılı ve kaçınan bağlanmayı negatif yönde, yalnızlık ise pozitif yönde yordamıştır. Duygusal bağımlılık ise kaygılı bağlanmayı pozitif yönde ve kaçınan bağlanmayı negatif yönde yordamıştır. Yeniden örnekleme yöntemi ile yapılan analiz sonuçlarına göre ise yalnızlık benlik saygısı ile kaçınan ve kaygılı bağlanma arasındaki ilişkilerde kısmi aracı rol oynarken duygusal bağımlılığın anlamlı bir aracı rolü bulunmamıștır. Elde edilen bulgular kuramsal temel ve alanyazındaki çalışmalar açısından tartışılmış ve gelecekte yapılabilecek çalışmalar için öneriler sunulmuştur.
\end{abstract}

Anahtar Kelimeler: Bağlanma, benlik saygısı, yalnızlık, duygusal bağımlılık, aracı etki.

\footnotetext{
* Bu çalışma için etik kurul izni 25/06/2021 tarih ve 2020/132 sayılı karar ile Düzce Üniversitesi Bilimsel Araștırma ve Yayın Etik Kurulu Bașkanlı̆̆ı'ndan alınmıștır.

** Orcid ID: https://orcid.org/0000-0002-7945-0906, Dr. Öğr. Üyesi, Düzce Üniversitesi, Türkiye, abdigungor@duzce.edu.tr

*** Orcid ID: https://orcid.org/0000-0002-4644-0963, Türkiye, kubraakabaa.96@gmail.com
}

Güngör, A., \& Kaba, K. (2021). Investigating the Effects of Self-Esteem on Attachment Styles in Individuals in Early Adulthood: The Mediating Roles of Emotional Dependency and Loneliness. Sakarya University Journal of Education, 11(3), 431-451. doi: https://doi.org/10.19126/suje.938197 


\section{GİRIŞ}

İlk yetişkinlik dönemi farklı kuramcılar tarafindan farklı yaş aralığında incelenmiş olmasına rağmen, Erikson tarafından bu dönem yakınlığa karşı yalıtılmışlık dönemi olarak kabul edilmiş olup 20-40 yaş aralığını kapsamaktadır. Bu dönemdeki bireylerin önde gelen temel gelişim görevlerinden birisi de sağlıklı ve doyum verici sosyal ve duygusal yakın ilişkiler kurabilmektir (Erikson, 1968). Eğer birey bu yakınlığı kuramazsa veya içten ilişkiler yaşayamazsa duygusal olarak kendini tamamlayamaz ve buna bağlı olarak ilişkileri yüzeysel kalır. İlişkilerinin derin olmadığını fark eden genç yetişkin ise kendini ilişkilerden soyutlamaya başlar ve bu dönemi sağlıklı bir şekilde geçirememiş olur (Burger, 2006; Havighurst, 1972; Levinson, 1986). İlk yetişkinlik dönemindeki bireylerin temel gelişim görevlerinden olan sağlıklı duygusal ve romantik ilişkiler kurma görevlerini başarılı bir şekilde yerine getirebilmelerinde bağlanma stilleri önemli bir rol oynamaktadır.

Bağlanma kavramı ilk olarak Bowlby'nin bebekler üzerinde yaptığg çalışmalarla ortaya atılmış olup (Bowlby, 1973, 1980), Ainsworth'un çalışmaları ile yetişkinlerin duygusal ve sosyal ilişkilerine yönelik de genişletilmiştir (Ainsworth, 1967). Temel olarak Bowlby bağlanma kavramını bebeğin kendisi için önemli olarak algıladığı kişilere karşı geliştirmiş olduğu duygusal bağ olarak tanımlamıştır (Bowlby, 1973). Alanyazında bağlanma stillerini farklı şekillerde sınıflandıran çalışmalar olsa da (Bartholomew ve Horowitz, 1991; Hazan ve Shaver, 1987), Ainsworth ve arkadaşları annenin davranış örüntülerini, anne-bebek arasındaki bağlanma stillerinin etkisini araştırarak bağlanma stillerinin kavramsallaştırılmasını sağlamış olup bebeklerin annelerine vermiş oldukları tepkilere karşı üç kategori belirlemiştir (Ainsworth, Bleahi, Waters ve Wall, 1978). Bu kategoriler güvenli, kaygılı/kararsız ve kaygılı/kaçınan bağlanmadır. Ainsworth ve arkadaşlarının sınıflandırması ile tutarlı bir şekilde, Hazan ve Shaver da (1987) yetişkin bağlanması için üç tür bağlanma tanımlamıştır. Bunlar güvenli, kaygılı-kararsız ve kaçınan bağlanmadır. Güvenli bağlanan kişi diğer bağlanma stiline sahip kişilere göre insanlarla iletişim kurmakta daha rahattır ve terk edilmek ya da birileri ile fazla yakın olduğunda rahatsız olmak gibi özelliklere sahip değildir. Kaçınan bağlanma stiline sahip bireyler ise karşılarındaki kişiye güvenmekte ve yakın olmakta zorlanırlar. Herhangi bir yakınlık söz konusu olduğunda bu onları rahatsız eder. Kaygılı-kararsız bağlanmada ise kişi kaçınan bağlanmaya sahip bireylerin aksine sürekli olarak yakınlık kurma arzusu içindedirler ve partnerlerinin aynı duygulara sahip olmadığına yönelik düşüncelere sahiptirler (Hazan ve Shaver, 1987).

Alanyazındaki çalışmalar bağlanma stilleri ile birçok değişken arasındaki ilişkiyi ortaya koymuştur. Örneğin, güvenli bağlanma, ilişkide algılanan tatmin (Sümer, 2006), evlilik uyumu (Senchak ve Leonard, 1992), ilişkisel benlik saygısı (Hamarta, 2004), umut ve güven (Simmons, Gooty, Nelson ve Little, 2009) ve koruyucu sağlık davranışı (Huntsinger ve Luecken, 2004) değişkenleriyle pozitif yönde ilişkili bulunmuştur. Diğer yandan kaygılı ve kaçınan bağlanma ilişki doyumu (Sarı ve Owen, 2016), cinsel doyum (Butzer ve Campbell, 2008), evlilik uyumunun alt boyutlarından anlaşma ve ilişki boyutu 
(Karabacak Çelik ve Çiftçi, 2020), evlilik doyumu (Sarı, 2012), benlik saygısı (Huntsinger ve Luecken, 2004; Ünlü, 2015)ile negatif yönde; depresyon (Karlığlu ve Parlar, 2020), depresif belirtilere yatkınlık (Scott ve Cordova, 2002) ve olumsuz çatışma çözme becerileri ve aldatma eğilimi (Kantarcı, 2009) ile pozitif yönde ilişkili bulunmuştur. Alanyazında da çokça ele alındığı gibi, bağlanma stilleri bireylerin sosyal ve duygusal/romantik ilişkilerinde önem arz eden bir konudur. Özellikle kaygılı ve kaçınan bağlanma stili bireylerin duygusal ve sosyal ilişkileri ve yaşam kaliteleri üzerinde olumsuz bir risk faktörü olarak değerlendirilebilir.

Üniversite öğrencileri ile yapılan çalışmalar da bağlanma stillerinin önemini göstermektedir. Üniversite öğrencileri ile yapılan çalışmalarda kaygılı ve kaçınmacı bağlanma stilleri, yaşam doyumu (Odacı, Çıkrıkçı, Çıkrıkçı ve Aydın, 2019; Tepeli Temiz ve Tarı Cömert, 2018), girişkenlik (Arfaei ve Najaryan, 2016), evlilik doyumu (Hamidi, 2007) ile negatif yönde ilişkili bulunmuştur. Diğer yandan kaygılı ve kaçınan bağlanma stilleri ile yalnızlık (Wiseman, Mayseless ve Sharabany, 2006), intihar düşüncesi (Taklavi ve Ghodrati, 2019) ve depresyon (Ahmadi, Daneshvarpoor ve Karimi, 2011) arasinda pozitif yönde ilişkiler bulunmuştur. Üniversite öğrencileri için, içinde bulundaki gelişim dönemi itibariyle sağlıklı ilişkiler geliştirmeleri önemli bir gelişim görevidir. $\mathrm{Bu}$ bağlamda ilk yetişkinlik dönemindeki bireyler örnekleminde, bağlanma stilleri ile ilişkili olabilecek faktörleri araştırmak, bu yönde kişilere sunulacak eğitimsel ve psikolojik desteklerin yapılandırılmasında faydalı olacaktır. $\mathrm{Bu}$ çalışmada ilk yetişkinlik dönemindeki benlik algısı, yalnızlık ve duygusal bağımlılık düzeyleri bağlanma stilleri üzerindeki etkileri açısından ele alınmıştır.

\section{Benlik Saygısı}

Kişinin kendisine yönelik olan olumlu ve olumsuz algıları Rosenberg (1965) tarafından benlik saygısı olarak tanımlanmıştır. Rogers (1959) ise benlik saygısını bebek ile bakım veren kişi arasında gelişen bağ ile ilişkilendirmiştir ve benlik saygısı yüksek olan kişilerin kendilerine yönelik algılarının olumlu yönde olduğunu belirtirken benlik saygısı düşük olan kişilerin ise kendilerine yönelik olan algılarının daha çok negatif olduğunu belirtmiştir. Rogers'ın da işaret ettiği gibi, benlik algısı bir yönüyle bebek ile bakım veren arasındaki ilişiyle ilgili olduğundan dolayı, kuramsal açıdan bireylerin kendilerini yönelik algıları sosyal veya duygusal/romantik ilişkilerindeki bağlanma stilleri üzerinde de etkili olabilecektir.

Alanyazındaki çalışmalarda, örneğin, benlik saygısı ile çift uyumu (Turanlı, 2010), ilişki doyumu (Kırıt Gülaydın ve Semerci, 2018), duygusal zeka (Bibi, Saqlain ve Mussawar, 2016), akademik performans (Arshad, Zaidi ve Mahmood, 2015; Saadat, Ghasemzadeh ve Soleimani, 2012), iyimserlik ve mutluluk (Dar ve Wani, 2017), yaşam doyumu (Arslan, Hamarta ve Uslu, 2010) ve güvenli bağlanma (Terzi ve Çankaya, 2009) arasında pozitif ilişki; stres ve depresyon (Ha, 2010), kaygı (Mustafa, Melonashi, Shkembi, Besimi ve Fanaj, 2015) internet bağımlılı̆̆ (Bahrainian, Alızadeh, Raeisoon, Gorji ve Khazaee, 2014) ve yalnızlık (Ahadi, 2009) ile negatif ilişki bulunmuştur. Benlik saygısı ile bağlanma stilleri arasındaki ilişkiyi araştıran çalışmalar da mevcuttur. Benlik saygısı ile 
güvenli olmayan bağlanma stilleri arasında negatif ilişki bulunmuştur (Çeçen, 2017; Dhal, Bhatia, Sharma ve Gupta, 2007; Tepeli Temiz, 2017; Turanll, 2010; Ünlü, 2015). Hem kuramsal açıdan bakıldığında hem de alanyazındaki çalışmaların da gösterdiği gibi benlik saygısı ile kaygılı ve kaçınan bağlanma stilleri arasında negatif yönde bir ilişki beklenmektedir.

Fakat bu ilişkiler arasında aracı etki rolünü oynayabilecek değişkenler de olabilir. Aracı değişken, iki veya daha fazla değişken arasında nasıl bir ilişki olduğunu açıklayan değişkendir (Preacher ve Hayes, 2004, 2008). Başka bir ifade ile aracı değişken bağımsız değişkenden bağımlı değişkene doğru olan yordayıcı etkinin hangi değişken(ler) üzerinden olduğunu ortaya koyarak, bağımlı değişken üzerinde merkezi rol oynayan faktörleri ortaya koymaktadır. Bu çalışmada da yalnızlık ve duygusal bağımlılığın benlik saygısı ve bağlanma stilleri arasındaki ilişkilerde aracı rolleri incelenmiştir. Yalnızlık ve duygusal bağımlılığın potansiyel aracı etkilerine yönelik hipotezlerin kuramsal ve alanyazındaki ampirik bulgulara göre dayandırıldığı temeller aşağıda açıklanmıştır.

\section{Yalnızlık}

Yalnızlık Erikson'a göre kimlik kazanımını başarılı bir şekilde tamamlayamayan kişilerin yakın ilişkiler kuramaması sonucunda ortaya çıkar (akt. Burger, 2006). Weiss (1973)'e göre ise yalnızlık durumunun meydana gelmesinde bağlanma, sosyal ilişkiler, özgeciliğin hakim olduğu ilişkiler, bireyin özelliklerinin değer görmesi, sosyal destek sistemi, ve rehberlik durumlarından birinin ya da birkaçının eksik olması etkilidir. Bu maddelerden birinin ya da birkaçının eksikliği durumunda ortaya çıkan yalnızlık fiziksel bir durumdan öte psikolojik bir durumdur ve bireyin etkileşimde olduğu sosyal ilişki ağı ile etkileşimde olmak istediği sosyal ilişki ağı arasındaki fark veya tezatlıktan ortaya çıkmaktadır. Kendini yalnız hisseden bireyler çevreleri ile bir ahenk içerisinde değillerdir, derin ve anlamlı ilişkiler yerine yüzeysel ilişkiler yaşarlar ve benmerkezci düşünceleri oldukça fazladır (Ünlü, 2015).

Yalnızlık, benlik saygısı ve psikolojik sağlamlık (Güloğlu ve Karaırmak, 2010; Karababa, 2021), sosyal destek (Avcı ve Yıldırım, 2014), güvenli bağlanma (Bernardon, Babb, Hakim Larson ve Gragg, 2011), duygusal bulaşma (Borawski, Wajs, Sojka ve Misztal, 2020), evlilik kalitesi (Isanejad ve Bagheri, 2018) ve akademik performans (Stoliker ve Lafreniere, 2015) kavramlarıyla negatif yönde ilişkili bulunmuştur. Diğer taraftan alanyazındaki çalışmalar yalnızlık ile şiddet eğilimi (Avcı ve Yıldırım, 2014), yabancılaşmanın alt boyutlarından olan yalıtılmışlık ve güçsüzlük (Atli, Keldal ve Sonar, 2015), kaygılı ve kaçınmacı bağlanma (Suri, Garg ve Tholia, 2019) ve online aldatma (Isanejad ve Bagheri, 2018) kavramlarıyla da pozitif yönde ilişkili olduğunu ortaya koymuştur.

\section{Duygusal Bağımlılık}

Duygusal bağımlılık bireyin duygusal yönden bağlanmaya yoğun bir şekilde ihtiyaç duymasıyla ortaya çıkan bir durumdur ve güvensiz bağlanma ve düşük benlik saygısı ile karakterize bir durum olarak ele alınmıştır (Arntz, 2006; Scantamburlo, Pitchot ve Anseau, 2013). Duygusal bağımlılığı yüksek bireyler yoğun bir yalnızlık ve boşluk 
duygusu ile sürekli olarak karşılarındaki kişiler ile ilişki kurma isteği içindedirler. Yoğun terk edilme inancına sahip olan bireyler bu inanç doğrultusunda eşleri veya sosyal çevrelerine bağlanırlar (Arntz, 2006). Bu kişiler aynı zamanda kendilerinin duygusal güvenliklerini ve istikrarlı duygu durumunu sağlayabileceğine dair inançtan yoksundurlar ve bunları sağlamak için bir başkasına ihtiyaç duyarlar. Bu boşluk duygusuyla kendilerinin başa çıkabileceğine inanmadıkları için de hep destek aramaktadırlar. Bu boşluk duygusu onlar için büyük ve yoğun bir durumdur ve bu kişiler güçlü bir kimlik duygusuna sahip olmadıkları için kendilerinde bununla baş edebilme becerisini görmemektedirler (Hoogstad, 2008).

Alanyazın incelendiğinde duygusal bağımlılık ile ilgili sınırlı çalışma olmasına rağmen, ilgili araştırmalar duygusal bağımlılık ile evlilik uyumu (Cirhinlioğlu, Kintap Tepe ve Cirhinlioğlu, 2017), ilişki doyumu (Kemer, Çetinkaya Yıldız ve Bulgan, 2016), anksiyete ve depresif belirtiler (Estévez, Urbiola, Iruarrizaga, Onaindia ve Jauregui, 2017) ve kaygllı bağlanma (Arbiol, Shaver ve Yarnoz, 2002) ile pozitif yönde ilişkili bulunurken istismara uğrayan bireylerde ilişkiyi sonlandırma (Bornstein, 2006), benlik saygısı (Estévez ve diğerleri, 2017) ile negatif ilişsili bulunmuştur.

\section{Yalnızlık ve Duygusal Bağımlılığın Aracı Rolü}

Kuramsal olarak benlik algısı düşük olan bireylerin kendilerine yönelik olumsuz algılarından dolayı ilişkilerinde de sorunlar yaşamaları olasıdır (Burger, 2006; Weiss, 1973). Alanyazında bunu destekler nitelikte çalışmalar da mevcuttur (örneğin, Atli ve diğerleri, 2015; Avcı ve Yıldırım, 2014; Isanejad ve Bagheri, 2018). Ayrıca yalnızlık ile de kaygılı ve kaçınan bağlanma arasında pozitif yönde bir ilişki olduğunu destekleyen çalışmalar mevcuttur (örneğin, Bernardon ve diğerleri, 2011; Suri ve diğerleri, 2019). Nitekim kişinin kendine yönelik olan olumsuz algıları kişinin sosyal ve romantik ilişkilerinde de sağlıklı ilişkiler kurmasını engellemekte ve bu durum da kişinin ilişkilerinde yüzeysel kalmasına ve derin ilişkiler kurmasına engel olan yalnızlığa yol açmaktadır (Rosenberg, 1965; Ünlü, 2015). Yalnızlık durumunda ise kişinin bakım veren kişiyle geliştirmiş olduğu bağa paralel olarak bağlanma sistemi etkili olur. Bu süreçte de kişinin içinde bulunmuş olduğu yalnızlık durumu ilişkilerinde daha fazla kaygılı veya kaçınan olmasına neden olur. Çünkü yalnızlık durumu güvenli bağlanma stiline sahip bireyler için baş edilebilecek bir durumdur. Yalnızlık durumu arttıkça kişinin güvensiz bağlanma stilleri de aktif olacaktır. Dolayısıyla düşük benlik algısının yüksek düzeyde yalnızlığı, bunun da yüksek düzeyde kaygılı ve kaçınan bağlanma stilini yordayacağı varsayılmaktadır.

Duygusal bağımlılığın aracı rolüne ilişkin olarak ise, benlik algısı ve güvensiz bağlanma duygusal bağımlılı̆̆ın tanımlanmasındaki temel kavramlardır (Arntz, 2006; Scantamburlo ve diğerleri, 2013). Duygu durumlarına yönelik bir istikrar sağlayamayacaklarına dair olumsuz inançları başta olmak üzere kendileri ile ilgili olumsuz algıları olan düşük benlik saygısına sahip bireylerin başkaları ile kuracakları ilişkide karşılarındaki kişiye yoğun bir bağlanma ihtiyacı duymaları beklenmektedir. Aynı zamanda karşılarındaki kişiye yoğun bağlanma ihtiyacı duyan duygusal bağımlılı̆̆ı 
yüksek kişilerin partnerlerine yönelik yoğun duygular içerisinde olan kaygılı bağlanma stilini de aynı yönde, yakın ilişkiler kurmaktan hoşlanmayan ve ilişkilerinde mesafeli olmayı tercih eden kaçınan bağlanma stiline sahip bireyleri de zıt yönde ilişki kurması beklenmektedir.Bu açıdan düşük benlik saygısına sahip bireylerin daha yüksek düzeyde duygusal bağımlığa, bunun da daha yüksek düzeyde güvensiz bağlanmayı yordaması öngörülmektedir. Duygusal bağımlılık ile bağlanma arasındaki ilişkiye dair, duygusal bağımlılığın kaygılı bağlanma ile pozitif yönde, kaçınan bağlanma ile de negatif yönde bir ilişkisi olduğu beklenmektedir.

Sonuç olarak, üniversite dönemi genel ortalama açısından ilk yetişkinlik dönemine karşılık gelmektedir ve bu dönemdeki bireylerin temel gelişim görevlerinin başında yakınlık duygusuna sahip olabilecekleri sosyal ve duygusal ilişkiler geliştirmek gelmektedir (Erikson, 1968; Havighurst, 1972; Levinson, 1986). Bu dönemde sağlıklı ilişkilerin kurulamaması durumunda meydana gelecek olan kriz durumu -yalıtılmış durumu- sonraki dönemler için de sağlıklı ilişkilerin kurulmasına engel olacak ve yaşamının tümünde oluşabilecek olumsuzluklara zemin hazırlayacaktır. Bu açıdan üniversite öğrencilerinin ilişkileri üzerinde önemli bir etkiye sahip olan bağlanma stillerinin üzerinde etkili olabilecek faktörleri araştırmak önem arz etmektedir. Bu çalışmada üniversite öğrencileri örnekleminde benlik saygısının kaygılı ve kaçınan bağlanma düzeyleri üzerindeki yordayıcı etkisi incelenmektedir. Ayrıca, bu çalışmanın bir diğer amacı da benlik saygısı ve bağlanma stilleri arasındaki ilişkilerde yalnızlık ve duygusal bağımlılığın aracı rollerini incelemektir. Dolayısıyla bağlanma stilleri üzerinde yalnızlık ve duygusal bağımlılığın merkezi rolleri daha iyi anlaşılmış olacaktır. Bu çalışma sonucunda yakınlık kurma döneminde olan bireyler için olumsuz olan durumların olumluya çevrilmesi konusunda yapılacak müdahaleler ve önleyici çalışmalar sağlıklı ilişki ve iletişim sürecinin sağlanması konusunda destekleyici olacaktır.

\section{YÖNTEM}

\section{Araştırma Grubu}

Bu çalışma için etik kurul izni 25/06/2021 tarih ve 2020/132 sayılı karar ile Düzce Üniversitesi Bilimsel Araştırma ve Yayın Etik Kurulu Başkanlığı'ndan alınmıştır. Araştırma grubunu 18-35 ( $\bar{x}=21,37 ; S=2,39)$ yaş aralığındaki üniversite öğrencileri oluşturmuştur. Katılımcılar 134'ü $(\% 25,87)$ erkek ve 384'ü $(\% 74,13)$ kadın olmak üzere toplam 518 gönüllü bireyden oluşmaktadır. Katılımcıların 119'u (\%22,97) birinci sınıf, 111'i $(\% 21,43)$ ikinci sınıf, 168'i $(\% 32,43)$ üçüncü sınıf, 68'i dördüncü sınıf $(\% 13,13)$ ve 52'si $(\% 10,04)$ lisansüstü öğrencisidir.

\section{Veri Toplama Araçları}

\section{Kişisel Bilgi Formu}

Araştırmacılar tarafından hazırlanan kişisel bilgi formu, katılımcıların yaş, cinsiyet ve sınıf düzeyi gibi demografik bilgilerini toplamak amacıyla kullanılmıştır. 


\section{UCLA Yalnızlık Ölçeği}

Bireylerin yalnızlık düzeylerini belirlemek amacıyla Russell, Peplau ve Ferguson (1978) tarafından geliştirilmiştir ve Demir (1989) tarafından Türkçe’ye uyarlanmıştır. Ölçekte toplam 20 maddeden oluşmaktadır ve bu maddelerin 10'u ters kodlanmıştır. Ölçek maddeleri 1 (hiç yaşamam) le 4 (sık sık yaşarım) arasında değişen 4'lü Likert tipinde oluşturulmuştur. Ölçekten alınabilecek toplam puan 20 ile 80 arasında değişmektedir ve yüksek puan daha yüksek yalnızlık seviyesine işaret etmektedir. Demir (1989) ölçeğin güvenirliğine ilişkin olarak iç tutarlık katsayısını ,94 olarak bulmuştur. Bu çalışmada ise iç tutarlık katsayısı ,92 olarak bulunmuştur.

\section{Yakın Illişkilerde Yaşantılar Envanteri II}

Fraley, Waller ve Brennan (2000) tarafından geliştirilmiştir ve Türkçe uyarlaması Selçuk, Günaydın, Sümer ve Uysal (2005) tarafından yapılmıştır. Ölçekte 7'li Likert tipinde 36 madde bulunmaktadır ve bu maddelerin 18 tanesi kaygılı bağlanma türünü ölçerken diğer 18 madde kaçınan bağlanma türünü ölçmektedir. Boyutlarla ilgili puanlar toplanarak her boyuta ait ayrı puan elde edilir. Yüksek puanlar ilgili bağlanma türünün düzeyinin yüksekliğine işaret eder. Kaçınmacı boyutunun iç tutarlık katsayısı ,90 iken kaygı boyutunun iç tutarlık katsayısı ,86 olarak rapor edilmiştir (Selçuk ve arkadaşları, 2005). Bu çalışmada ise iç tutarlık katsayıları kaçınmacı bağlanma için ,91 ve kaygılı bağlanma için ,89 olarak bulunmuştur.

\section{Duygusal Bağımlılık Ölçeği}

Buunk (1981) tarafından geliştiren ölçek Karakurt (2001) tarafından Türkçe'ye uyarlanmıştır. Ölçek biri ters kodlanan 7'li Likert tipinde toplam dokuz maddeden oluşmaktadır. Ölçekten alınan yüksek puan duygusal bağımlılığın yüksek olduğunu göstermektedir. Buunk (1981) iç tutarlık katsayısını ,81 olarak rapor etmiştir. Bu çalışmada ise iç tutarlık katsayısı ,89 olarak bulunmuştur.

\section{Rosenberg Benlik Saygısı Ölçeği (RBSÖ)}

Rosenberg (1965) tarafından geliştirilen ölçek kişinin kendisini değerlendirmesine yöneliktir. Ölçeğin Türkçe'ye uyarlaması Çuhadaroğlu (1986) tarafından yapılmıştır. Ölçek 63 madde ve 12 alt boyuttan oluşmaktadır ve 4'lü Likert tipi derecelendirme kullanılmıştır. $\mathrm{Bu}$ araştırmada sadece 10 maddelik benlik saygısı alt boyutu kullanılmıştır. Ölçekteki beş madde ters kodlanmıştır. Ölçekten alınabilecek en düşük puan 10 en yüksek puan 40tır. Ölçekten alınan puanların yükselmesi benlik saygısının yükseldiğini göstermektedir. Çuhadaroğlu (1986) güvenirlik katsayısını ,75 olarak rapor etmiştir. Bu çalışmada ise iç tutarlılık katsayısı ,87 olarak bulunmuştur.

\section{İşlem}

Araştırma için veri toplama sürecine geçmeden önce, gerekli etik ve idari izinler alınmıştır. Veriler, online bir platforma aktarılan link aracılığıyla online bir şekilde toplanmıştır. Veri toplama araçlarından önce katılımcılarla araştırmanın amacı, önemi ve kapsamı ile ilgili bir açıklama paylaşılmıştır. Ayrıca katılımcılara araştırmaya katılmaya gönüllü olup olmadıkları ile ilgili bir soru sorulmuştur ve gönüllülük ve gizlilik 
vurgulanmıştır. Veriler SPSS 22.00 paket programı ile analiz edilmiştir ve bulguların yorumlanmasında ,05 anlamlılık düzeyi esas temel alınmıştır.

Verilerin analizinde iki aşama takip edilmiştir. Öncelikle verilerin uygulanacak istatistiksel yöntemler için uygunluğu test edilmiştir. İkinci aşamada ise bağımsız değişkenlerin bağımlı değişkenleri yordayıp yordamadıkları test edilmiştir. $\mathrm{Bu}$ kapsamda, kaygılı bağlanma ve kaçınan bağlanmayı (bağımlı değişkenler) benlik saygısı, yalnızlık ve duygusal bağımlılı̆̆ın (bağımsız değişkenler) ne derece yordadıklarını anlamak için iki adet hiyerarşik regresyon analizi yapılmıştır. Ayrıca, yalnız ve duygusal bağımlılığın, benlik saygısı ve bağlanma stilleri arasındaki aracı rolünü test etmek amacıyla paralel aracı değişken analizi yapılmıştır. Aracı etkinin anlamlılığını test etmek için SPPS-macro programı ile yeniden örnekleme yöntemi (bootstrapping) kullanılarak 10.000 tekrarlı deneme (iteration) yöntemi kullanılmıştır (Preacher ve Hayes, 2004, 2008).

İlk aşama kapsamında uç değerler, değişkenler arasında çoklu bağlantı (multicollinearity), varyans genişlik faktörü (VIF) ve tolerans değerleri incelenmiştir. Mahalonobis uzaklık değerleri yöntemiyle üç tane uç değer tespit edilmiş ve veri setinden çıkarılmıştır. Basıklık (kurtosis) değerleri ,03 ile ,97 arasında, çarpıklık (skewness) değerleri ise ,24 ile-1,06 arasında değişmektedir. Sonuç olarak, veri setinin normallik varsayımını karşıladığı belirlenmiştir (Pallant, 2010; Tabachnick ve Fidell, 2013). Çoklu bağlantı problemi açısından, VIF değerlerinin 10'dan küçük olduğu ve tolerans seviyelerinin de ,10'dan büyük olduğu bulunmuştur. Ek olarak, bağımsız değişkenler arasındaki ilişki -,02 ile -,48 arasında değişmektedir. Bu sonuçlar bağımsız değişkenler arasında çoklu bağlantı probleminin olmadığını göstermektedir. Sonuç olarak, veriler gerekli varsayımları karşılamıştır ve analizlerde ikinci aşamaya geçilmiştir.

\section{BULGULAR}

Bağımlı ve bağımsız değişkenler arasındaki ilişkiler ve değişkenlere dair betimsel istatistikler Tablo 1'de gösterilmiştir. Pearson Momentler Çarpım Korelasyon Katsayısı sonuçlarına göre, kaygılı bağlanma ile benlik saygısı $(r=-, 49, p<, 01)$ arasında negatif anlamlı bir ilişki, yalnızlık $(r=, 42, p<, 01)$ ve duygusal bağımlılık $(r=, 12, p<, 01)$ arasında ise pozitif anlamlı bir ilişki vardır. Kaçınan bağlanma ise benlik saygısı $(r=-, 39, p<, 01)$ ve duygusal bağımlılık $(r=-, 27, p<, 01)$ ile negatif anlamlı bir şekilde, yalnızlık $(r=, 39$, $p<, 01)$ ile de pozitif anlamlı bir şekilde ilişkilidir. 
Tablo 1.

Kaygılı Bağlanma, Kaçınan Bağlanma, Benlik Saygısı, Yalnızlık ve Duygusal Bağımlılık Arasındaki İlişkiler ve Değişkenlere İlişkin Betimsel İstatistikler

\begin{tabular}{llllll}
\hline Değişkenler & 1 & 2 & 3 & 4 & 5 \\
\hline Kaygılı Bağlanma & 1 & & & & \\
Kaçınan Bağlanma &, $39^{* *}$ & 1 & & & \\
Benlik Saygısı &,$- 49^{* *}$ &,$- 39^{* *}$ & 1 & & \\
Yalnızlık &, $42^{* *}$ &, $39^{* *}$ &,$- 48^{* *}$ & 1 & \\
Duygusal Bağımlılık &, $12^{* *}$ &,$- 27^{* *}$ &,- 02 &, $09^{*}$ & 1 \\
$\bar{X}$ & 60,69 & 54,82 & 30,70 & 33,71 & 32,74 \\
$S S$ & 17,93 & 18,81 & 4,95 & 10,16 & 11,84 \\
\hline
\end{tabular}

${ }^{*} p<, 05,{ }^{* *} p<, 01$

\section{Kaçınan Bağlanma Puanlarının Yordanması}

Benlik saygısı, yalnızlık ve duygusal bağımlılık puanlarının kaçınan bağlanma puanlarını yordamasını test etmek amacıyla iki aşamalı bir hiyerarşik regresyon analizi yapılmıştır (Tablo 2). İlk aşamada benlik saygısının tek başına kaçınan bağlanmayı yordaması test edilmiştir. Sonuca göre, benlik saygısı kaçınan bağlanmayı anlamlı bir şekilde negatif yönde yordamıştır ve varyansın \%16'sını açıklamıştır. İkinci aşamada, modele yalnızlık ve duygusal bağımlılık da eklenmiştir ve açıllanan varyansa \%14'lük bir katkı sağlamıştır. Son durumda bütün bağımsız değişkenler beraber toplam varyansın \%30'unu açıklamıştır. İkinci aşamada yalnızlık ve duygusal bağımlılık modele eklenince benlik saygısının etkisi $\beta=-, 39$ 'dan $\beta=-, 26$ ya düşmüştür. Bu sonuç yalnızlık ve duygusal bağımlılığının muhtemel aracı etkisini göstermektedir fakat bu etkinin düzeyini belirlemek için daha ileri bir analiz gerekmektedir.

Tablo 2.

Kaçınan Bağlanma Stilinin Yordanmasına İlişkin Hiyerarşik Regresyon Analizi Sonuçları

\begin{tabular}{|c|c|c|c|c|c|c|c|c|}
\hline Değişkenler & $R^{2}$ & $\Delta R^{2}$ & $B$ & $\begin{array}{c}\text { Standart } \\
\text { Hata }\end{array}$ & $B$ & $T$ & $P$ & $F$ \\
\hline Adım 1 & ,16 & & & & & & & $96,69 * * *$ \\
\hline Benlik Saygısı & & & $-1,51$ & ,15 &,- 39 & $-9,83$ & ,000 & \\
\hline Adım 2 & ,30 &, $14^{* * *}$ & & & & & & $74,21^{* * *}$ \\
\hline Benlik Saygısı & & &,- 99 & ,16 &,- 26 & $-6,16$ & ,000 & \\
\hline Yalnızlık & & &, 55 & ,08 & ,29 & 7,01 & ,000 & \\
\hline Duygusal Bağımlılık & & &,- 49 & ,06 &,- 31 & $-8,25$ &, 000 & \\
\hline
\end{tabular}




\section{Kaygılı Bağlanma Puanlarının Yordanması}

Bağımsız değişkenlerin kaygılı bağlanma puanlarını yordamasını test etmek amacıyla diğer bir iki aşamalı hiyerarşik regresyon analizi yapılmıştır (Tablo 3). İlk aşamada benlik saygısı tek başına kaygılı bağlanmayı anlamlı bir şekilde negatif yönde yordamıştır ve varyansın \%24'ünü açıklamıştır. İkinci aşamada ise modele eklenen yalnızlık ve duygusal bağımlılık da açıklanan varyansa \%5'lik bir katkı sağlamıștır. Son durumda bütün bağımsız değişkenler beraber toplam varyansın \%29'unu açıklamıştır. İkinci aşamada yalnızlık ve duygusal bağımlılık modele eklenince benlik saygısının etkisi $\beta=-, 49$ 'dan $\beta=-, 38$ 'e düşmüştür. Bu sonuç yalnızlık ve duygusal bağımlılığının benlik saygısı ve kaygılı bağlanama arasında potansiyel aracı etkisini göstermektedir fakat bu etkinin düzeyini belirlemek için daha ileri bir analiz gerekmektedir.

Tablo 3.

Kaygılı Bağlanma Stilinin Yordanmasına İlişskin Hiyerarşik Regresyon Analizi Sonuçları

\begin{tabular}{|c|c|c|c|c|c|c|c|c|}
\hline Değişkenler & $R^{2}$ & $\Delta R^{2}$ & $B$ & $\begin{array}{c}\text { Standart } \\
\text { Hata }\end{array}$ & $B$ & $T$ & $P$ & $F$ \\
\hline Adım 1 & ,24 & & & & & & & $1665,92^{* * *}$ \\
\hline Benlik Saygısı & & & $-1,79$ & ,14 &,- 49 & $\begin{array}{c}- \\
12,88\end{array}$ & ,000 & \\
\hline Adım 2 & ,29 &, $05^{* * *}$ & & & & & & $72,34^{* * *}$ \\
\hline Benlik Saygısı & & & $-1,37$ & ,15 &,- 38 & $-8,98$ & ,000 & \\
\hline Yalnızlık & & & ,41 & ,08 & ,23 & 5,46 & ,000 & \\
\hline $\begin{array}{l}\text { Duygusal } \\
\text { Bağımlılık }\end{array}$ & & & ,14 & ,06 & ,09 & 2,49 & ,013 & \\
\hline
\end{tabular}

$* * * p<, 001$

\section{Yalnızlık ve Duygusal Bağımlılığın Aracı Etkisine Ait Bulgular}

Bir aracı değişkenin olabilmesi için üç şart gerekmektedir. İlk şarta göre bağımsız değişkenin aracı değişkeni, ikinci şarta göre de bağımsız değişkenin bağımlı değişkeni anlamlı bir şekilde yordaması gerekir. Üçünü şarta göre de aracı değişken modele eklendiğinde, bağımsız değişkenin etkisinin ortadan kalması veya azalması gerekir (Baron ve Kenny, 1986). Hiyerarşik regresyon sonuçlarına göre hem kaçınan hem de kaygılı bağlanma yordanırken ikinci ve üçüncü şartlar halihazırda karşılanmıştır.

Benlik saygısı ile kaçınan bağlanma arasındaki ilişkide yalnızlık ve duygusal bağımlılığın aracı etkisine dair yeniden örnekleme yöntemi ile yapılan analizin sonuçları Şekil 1'de gösterilmiştir. Şekilde benlik saygısından yalnızlık ve duygusal bağımlılığa, yalnızlık ve duygusal bağımlılıktan kaçınan bağlanmaya ve benlik saygısından kaçınan bağlanmaya doğrudan ve toplam etkiler gösterilmiştir. Benlik saygısında yalnızlığa olan etkinin 
anlamlı olduğu ve yalnızlık üzerinden olan dolaylı etkinin \%95 güven aralığının sıfır değerini içermediği görülmüştür $[-, 73$ ve-,38 aralığı]. Benlik saygısından duygusal bağımlılığa olan etkinin anlamsız olduğu görülmektedir. Dolaysıyla duygusal bağımlılık aracı etki şartlarını karşılamadığı ve ayrıca duygusal bağımlılık üzerinden olan aracı etkinin \%95 güven aralığının sıfır değeri içerdiği bulunmuştur [-,09 ve ,13 aralığı]. Ek olarak benlik saygısından kaçınan bağlanmaya olan doğrudan etkinin hala anlamlı olduğu görülmektedir. Bu sonuçlara göre, yalnızlık benlik saygısı ve kaçınan bağlanma arasından kısmi aracı rol oynarken, duygusal bağımlılığın anlamlı bir aracı rolü yoktur.

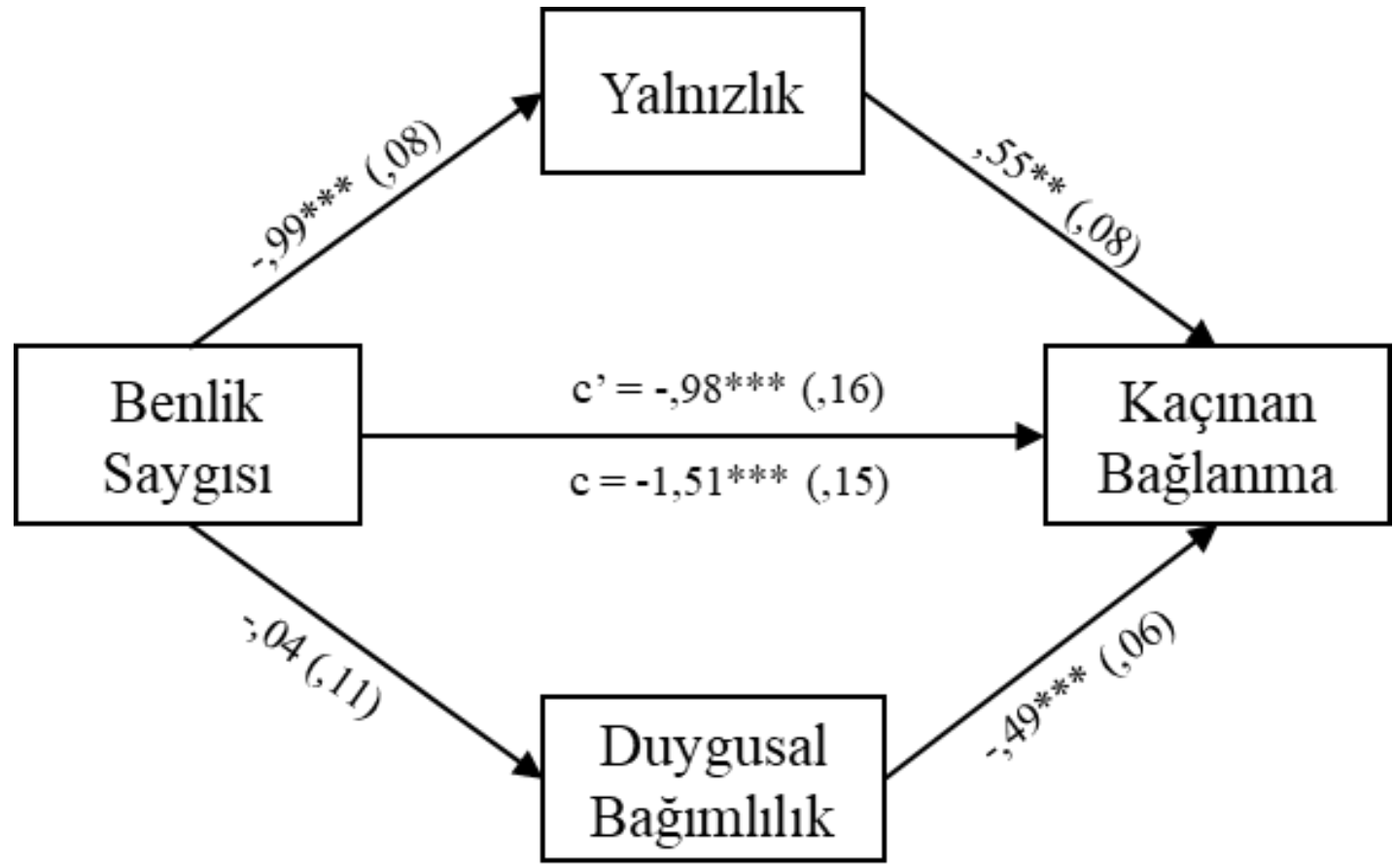

Şekil 1. Yalnızlık ve Duygusal Bağımlılığın Benlik Saygısı ve Kaçınan Bağlanma Arasındaki İlişkide Aracı Rolü. Bütün etki değerleri standartlaştırılmamış değerlerlerdir ve standart hatalar parantez içinde gösterilmiştir. c' değeri benlik saygısının kaçınan bağlanmaya olan doğrudan etkiyi göstermekte; c değeri benlik saygısının kaçınan bağlanmaya olan toplam etkiyi göstermektedir.

Benlik saygısı ile kaygılı bağlanma arasındaki ilişkide yalnızlık ve duygusal bağımlılığın aracı rolüne dair yapılan analizin sonuçları Şekil 2'de gösterilmiştir. Benlik saygısında yalnızlığa olan etkinin anlamlı olduğu ve yalnızlık üzerinden olan dolaylı etkinin \%95 güven aralığının sıfır değerini içermediği görülmüştür [-,60 ve -,24 aralığı]. Benlik saygısından duygusal bağımlılığa olan etkinin anlamsız olduğu görülmektedir. Dolaysıyla duygusal bağımlılık aracı etki şartlarını karşılamadığı ve ayrıca duygusal bağımlılık üzerinden olan aracı etkinin \%95 güven aralığının sıfır değeri içerdiği bulunmuştur [-,05 ve ,02 aralığı]. Ek olarak benlik saygısından kaygılı bağlanmaya olan doğrudan etkinin hala anlamlı olduğu görülmektedir. Bu sonuçlara göre, yalnızlık benlik saygısı ve kaygılı bağlanma arasından kısmi aracı rol oynarken, duygusal bağımlılığın aracı rolü anlamsızdır. 


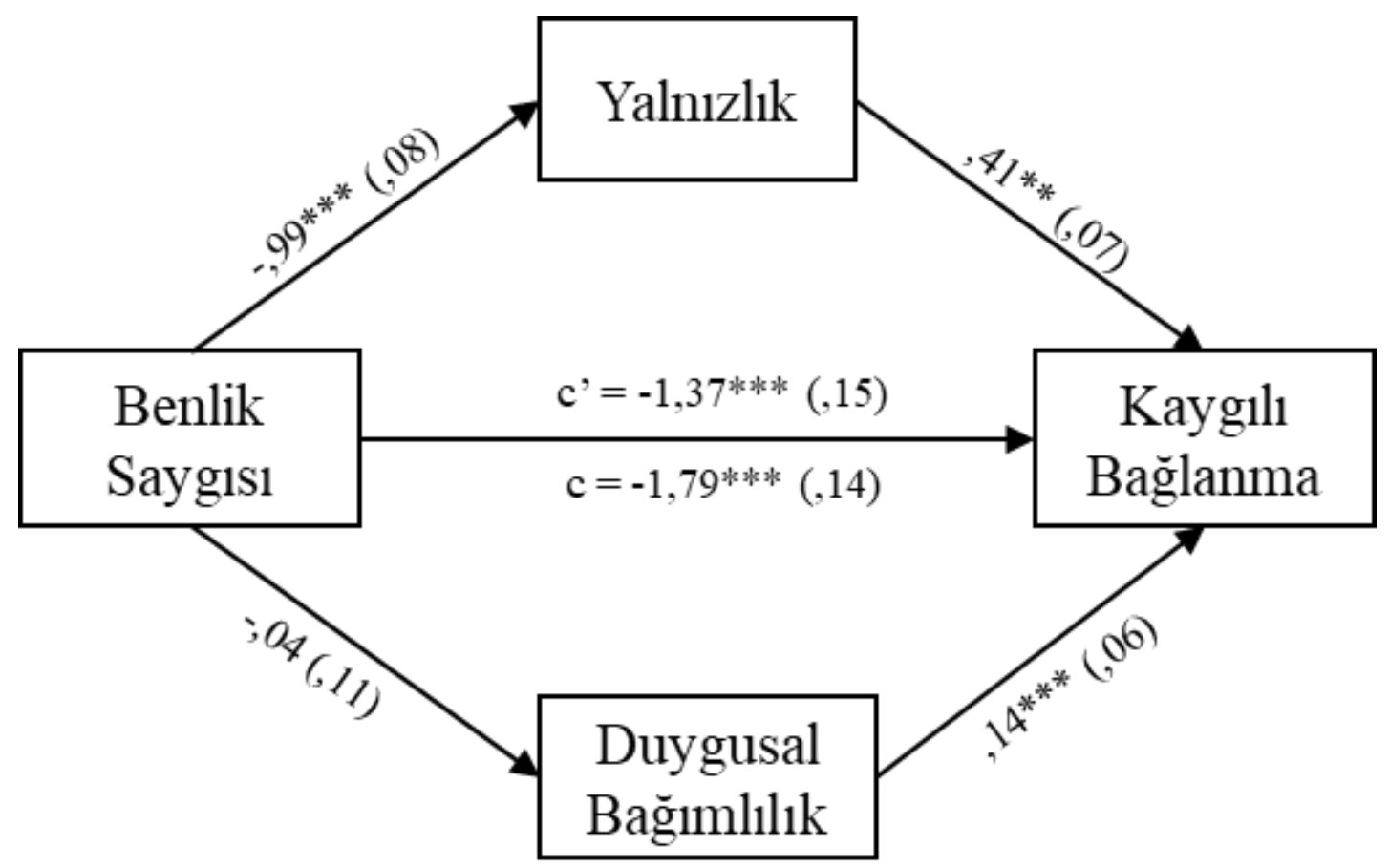

Şekil 2. Yalnızlık ve Duygusal Bağımlılığın Benlik Saygısı ve Kaygılı Bağlanma Arasındaki İlişkide Aracı Rolü. Bütün etki değerleri standartlaştırılmamış değerlerlerdir ve standart hatalar parantez içinde gösterilmiştir. c' değeri benlik saygısının kaygılı bağlanmaya doğrudan etkiyi göstermekte; c değeri benlik saygısının kaygılı bağlanmaya toplam etkiyi göstermektedir.

\section{SONUÇ, TARTIŞMA VE ÖNERİLER}

İlk yetişkinlik dönemindeki bireylerin içlerinde bulundukları gelişim dönemi itibariyle duygusal ve sosyal ilişkilerinde sağlıklı ve içten bir yakınlık kurmalarındaki en önemli faktörlerden birisi kişinin bağlanma stilidir. Güvenli bağlanan ve güvensiz bağlanan kişilerin ilişki ve evlilik doyumları, anksiyete düzeyleri, akılcı olmayan inançları, depresyon düzeyleri ve daha birçok faktör değişkenlik göstermektedir. Bu araştırmada bireylerin benlik saygısı ile bağlanma stilleri arasındaki ilişki incelenmiş olup ayrıca bu ilişkide duygusal bağımlılığın ve yalnızlığın aracı rolü araştırılmıştır.

Bulgular benlik saygısı ile kaçınan ve kaygılı bağlanma arasında negatif yönlü anlamlı bir ilişki olduğunu göstermiştir. Rosenberg'e (1965) göre benlik saygısı kişinin kendisine yönelik düşüncelerini temsil eder. Kaçınan bağlanma stiline sahip bireylerin diğer kişilerle yakın temas kurmakta zorlanması ve güvenmekte zorlanması ve kayglı bağlanma stiline sahip bireylerin ise sürekli partnerleri tarafından terk edileceğine dair inançları mevcuttur (Hazan ve Shaver, 1987). Dolayısıyla, bu kuramsal temel benlik saygısı ile kaygılı ve kaçınan bağlanma stilleri arasında negatif yönlü bir ilişkinin bulunmasını destekler niteliktedir. Alanyazın incelendiğinde de bu sonuçları destekleyen araştırmalar mevcuttur (Çeçen, 2017; Tepeli Temiz, 2017; Turanl, 2010). $\mathrm{Bu}$ sonuçlara göre bireylerin benlik saygısı azaldıkça kaygılı ve kaçınan bağlanma stiline ait puanları artmaktadır. 
Araştırmanın diğer bulgusunu ise yalnızlık ile kaçınan ve kaygılı bağlanma stilleri arasındaki pozitif ilişki oluşturmaktadır. Kişinin yakın ilişkiler içinde bulunamaması sonucu yalnızlık ortaya çıkmaktadır (Burger, 2006). Bu durum da kuramsal olarak bulguları destekler niteliktedir. Alanyazın incelendiğinde literatürdeki sonuçlar da araştırmadaki bulgular ile paralellik göstermektedir (Suri ve diğerleri, 2019; Wiseman ve diğerleri, 2006). Sonuç olarak kişinin yalnızlık puanları arttıkça kaçınan ve kaygılı bağlanma puanları da artmaktadır.

Duygusal bağımlılık ile bağlanma stilleri arasındaki ilişkiye dair bulgulara göre ise duygusal bağımlılık ile kaygılı bağlanma arasında pozitif yönde anlamlı bir ilişki, kaçınan bağlanma ile de negatif yönde anlamlı bir ilişki olduğu görülmektedir. Kişinin başka birisine karşı duygusal anlamda bağlanma ihtiyacını yoğun olarak yaşaması olarak karşımıza çıkan duygusal bağımlılık (Arntz, 2006) ile partneriyle sürekli yakın temasta olmak isteği şeklinde görülen kaygılı bağlanma stili arasında pozitif ve yakın temasta bulunmaktan hoşlanmayan kaçınmacı bağlanma stili arasında negatif (Hazan ve Shaver, 1987) ilişki bulunması beklenen bir durumdur. Alanyazında bu bulguları destekleyen çalışmalar da mevcuttur (Arbiol ve diğerleri, 2002). Sonuç olarak bu bulgular duygusal bağımlılık arttıkça kaygılı bağlanma düzeyinin de arttığını fakat kaçınan bağlanma düzeyinin azaldığını göstermektedir.

Ayrıca araştırmada benlik saygısı ile kaçınan ve kaygılı bağlanma stilleri arasında yalnızlık ve duygusal bağımlılığın aracı rolü de incelenmiştir. Yalnızlık benlik saygısı ile kaçınan ve kaygılı bağlanma arasında kısmı aracı rol oynamıştır. Bu sonuca göre kişinin benlik saygısı azaldıkça yalnızlık düzeyi artmaktadır. Yalnızlık düzeyinin artmasına bağlı olarak da kaygılı ve kaçınan bağlanma stilinde artış yaşanmaktadır. Bu anlamda, yalnızlığın anlamlı bir kısmi aracı rolünü olması kaygllı ve kaçınmacı bağlanma stillerinin yordanmasındaki merkezi rolüne vurgu yapmaktadır. Fakat yine de benlik saygısının anlamlı doğrudan etkisi de göz önünde bulundurulmalıdır.

Duygusal bağımlılık benlik saygısı ile kaçınan ve kaygılı bağlanma arasında aracı değişken rolü oynamamaktadır. Hiyerarşik regresyon bulgularının da ortaya koyduğu üzere, duygusal bağımlılık kaygılı bağlanmayı pozitif kaçınmacı bağlanmayı negatif yönde doğrudan yordamıştır. Fakat benlik saygısının duygusal bağımlılığı anlamlı bir şekilde yordamadığı görülmüştür. Bu noktada kişinin partnerine yönelik yoğun ilişki kurma ihtiyacı ve istikrarlı duygu durumu üzerinde kişinin kendisine yönelik oluşturmuş olduğu algıların ötesinde farklı bileşenler etkili olabilir. Duygusal bağımlılık olumlu benlik saygısına sahip bireyler için de olumsuz benlik saygısına sahip bireyler için de farklılık göstermemektedir. Bu konuda daha fazla araştırma yapılması gerekmektedir.

Bu noktada kişinin benlik saygısını arttırmaya yönelik yapılacak etkinlik ve girişimler kişilerin güvensiz bağlanma türleri olan kaygılı ve kaçınan bağlanma stillerinin azaltılmasında etkili olabilecektir. Kişinin benlik saygısını arttırmaya yönelik bireyle ve grupla psikolojik danışma uygulamaları faydalı olabilir. Aynı zamanda psiko-eğitim programlarına da başvurulabilir. Ayrıca ilk yetişkinlik döneminde olan üniversite 
öğrencilerine yönelik akademik, sosyal ve kültürel etkinlikler de onların benlik saygılarını arttırmaya, böylelikle ilişkilerinde daha güvenli bağlanma stillerine sahip olmalarına katkı sağlayabilir. Böylece kişinin kendisini kendi değerini fark etmesine yönelik yapılacak etkinlikler güvenli bağlanma stiline doğru değişim göstermesi noktasında etkili olabilir.

Araştırma bulgularının gösterdiği gibi yalnızlığın anlamlı kısmi aracı rolü göz önüne alındığında, bireyin yalnızlığını azaltmak da kişinin daha güvenli bir bağlanma stiline doğru değişim göstermesine katkı sağlayabilir. Kişinin yalnızlık duygusuyla baş edebilmesi için sosyal destek sistemini güçlendirme, olumlu özellikleri pekiştirerek kendine olan güvenini destekleme ve sosyal ilişkilerinde destekleme adımları izlenebilir. $\mathrm{Bu}$ anlamda özellikle sosyal ve kültürel faaliyetler ve imkanların sağlanması, gerektiğinde bireyle veya grupla müdahale ve destek hizmetlerinim sunulması kişilerin yalnızlık duygusuyla baş etmelerinde faydalı olacaktır. Yine bu doğrultuda, üniversite öğrencilerinin yalnızlık düzeyleri tespit etmek amacıyla taramalar ve sonuçlara göre önleyici ve müdahale hizmetleri geliştirme mümkün olacaktır. Böylece bireylerin yalnızlık ile baş edebilmesi ve güvenli bağlanma stiline yönelimi kişinin özellikle doyurucu ilişkiler geliştirmelerinde olumlu katkılar sağlayacaktır.

Fakat her araştırmada olduğu gibi bu araştırmada da bazı sinırlılıklar mevcuttur. Araştırma modeli korelasyonel bir araştırmadır dolayısıyla net bir neden-sonuç ilişkisinde bahsetmek mümkün değildir. Fakat yine de yordayıcı bulgular kuramsal bakış açısında göre tartışılmıştır. Bu anlamda daha kesin neden-sonuç ilişkisinden bahsetmek için ilerideki araştırmalar deneysel veya boylamsal yöntemleri kullanabilir. Ayrıca kadın ve erkek katılımcı sayısı arasında bir dengesizlik mevcuttur. İlerleyen çalışmalarda bu dengesizliğin aşılması da göz önünde bulundurulabilir.

\section{Kaynaklar}

Ahadi, B. (2009). Relationship between loneliness and self- esteem with students' attachment styles. Quarterly Journal of Psychological Studies, 5(1), 95-112. doi: 10.22051/PSY.2009.1593

Ahmadi, T. S. M., Daneshvarpoor, Z. ve Karimi, L. (2011). The relationship between attachment styles and depression in university students. Journal of Sabzevar University of Medical Sciences, 18(3), 217-223.

Ainsworth, M. D. S., Blehai, M. C., Waters, E. ve Wall, S. (1978). Patterns of attachment: A psychological study of the strange situation. Hillsdale, NJ: Erlbaum.

Ainsworth, M.D.S. (1967). Infancy in Uganda: Infant care and the growth of love. Baltimore: John Hopkins University Press.

Arbiol, I. A., Shaver, P. R. ve Yarnoz, S. (2002). Insecure attachment, gender roles, and interpersonal dependency in Basque Country. Personal Relationship, 9(4), 479-490. doi: 10.1111/1475-6811.00030 
Arfaei, F. S. ve Najaryan, Z. (2016). The Relationship among attachment styles \& sssertiveness among University Students. Rooyesh, 4(4), 35-48.

Arntz, A. (2006). Dependency: Distinguishing functional from emotional dependency. Clinical Psychology: Science and Practice, 12(4), 411-416.

Arshad, M., Zaidi, S. M. I. M. ve Mahmood, K. (2015). Self esteem \& academic performance among university students. Journal of Education and Practice, 6(1), 156-162.

Arslan, C., Hamarta, E. ve Uslu, M. (2010). The relationship between conflict communication, self esteem and life satisfaction in university students. Educational Research and Reviews, 5(1), 31-34.

Atli, A., Keldal, G. ve Sonar, O. (2015). Üniversite öğrencilerinin yabancılaşma ve yalnızlık düzeyleri arasındaki ilişki. Mustafa Kemal Üniversitesi Sosyal Bilimler Enstitüsü Dergisi, 12(29), 149-160.

Avcı, Ö. H. ve Yıldırım, İ. (2014). Ergenlerde şiddet eğilimi, yalnızlık ve sosyal destek. Hacettepe Üniversitesi Ĕ̆itim Fakültesi Dergisi, 29(1), 157-168.

Bahrainian, S. A., Alızadeh, K. H., Raeisoon, M. R., Gorji, O. H. ve Khazaee, A. (2014). Relationship of internet addiction with self-esteem and depression in university students. Journal of Preventive Medicine and Hygiene, 55(3), 86-89.

Baron, R. M. ve Kenny, D. A. (1986). The moderator-mediator variable distinction in social psychological research: Conceptual, strategic, andstatistical considerations. Journal of Personality and Social Psychology, 51(6), 1173-1182.

Bartholomew, K. ve Horowitz, L. (1991). Attachment styles among young adults: A test of a four category model. Journal of Personality and Social Psychology, 61, 226-244.

Bernardon, S., Babb, K. A., Hakim-Larson, J. Ve Gragg, M. (2011). Loneliness, attachment, and the perception and use of social support in university students. Canadian Journal of Behavioural Science / Revue canadienne des sciences du comportement, 43(1), 4051. doi: 10.1037/a0021199

Bibi, S., Saqlain, S. ve Mussawar, B. (2016). Relationship between emotinal intelligence and self esteem among Pakistani university students. Journal of Psychology \& Psychotherapy, 6(4), 1-6. doi: 10.4172/2161-0487.1000279

Borawski, D., Wajs, T., Sojka, K. ve Misztal, U. (2020). Interrelations between attachment styles, emotinal contagion and loneliness. Journal of Family Issues, 42(3), 2064-2082. doi: 10.1177/0192513X20966013

Bornstein, R. F. (2006). The complex relationship between dependency and domestic violence: Converging psychological factors and social forces. American Psychologist, 61(6), 595-606. doi: 10.1037/0003-066X.61.6.595.

Bowlby, J. (1973). Attachment and loss. Separation, anxiety and anger. New York: Basic Books. 
Bowlby, J. (1980). Attachment and Loss, vol. 3: Loss-Sadness and Depression. New York: Basic Books.

Burger, J.M. (2006). Kişilik: Psikoloji biliminin insan doğasına dair söyledikleri. İstanbul: Kaknüs Yayınları.

Butzer, B. ve Campbell, L. (2008). Adult attachment, sexual satisfaction, and relationship satisfaction: A study of married couples. Personal Relationships, 15(1),141154. doi:10.1111/j.1475-6811.2007.00189.x.

Buunk, B. (1981). Jealousy in sexually open marriages. Alternative Lifestyle, 4(3), 357372. doi: 10.1007/BF01257944

Cirhinlioğlu, F. G., Kindap Tepe, Y. ve Cirhinlioğlu, Z. (2017). Psychological distress, self esteem and emotional dependency of married individuals as predictors of marital adjustment. Procedia Computer Science, 120(2017), 164-171. doi: 10.1016/j.procs.2017.11.224

Çeçen, D. (2017). Yetişkinlerde Bağlanma stilleri ile benlik saygısı ve sürekli kaygı düzeyi arasındaki ilişkinin incelenmesi. (Yayımlanmamış Yüksek Lisans Tezi). Haliç Üniversitesi, İstanbul.

Çuhadaroğlu,F. (1986). Adolesanda benlik saygısı (Uzmanlık Tezi). Hacettepe Üniversitesi, Ankara.

Dar, A. A. ve Wani, M. A. (2017). Optimisim, happiness and self- esteem among university students. Indian Journal of Positive Psychology, 8(3), 275-279.

Demir, A. (1989). U.C.L.A. Yalnızlık ölçeğinin geçerlik ve güvenirliği. Psikoloji Dergisi, 7(28), 14-18.

Dhal, A., Bhatia, S., Sharma, V. ve Gupta, P. (2007). Adolescent self-esteem, attachment and loneliness. Journal of Indian Association for Child and Adolescent Mental Health, 3, 61-63.

Erikson, H. E. (1968). Identity, youth and crisis. W. W. Norton Company.

Estévez, A., Urbiola, I., Iruarrizaga, I., Onaindia, J. ve Jauregui, P. (2017). Emotional dependency in dating relationships and psychological consequences of internet and mobile abuse. Anales de Psicología, 33(2), 260-268. doi: 10.6018/analesps.33.2.25511

Fraley, R. C., Waller, N. G. ve Brennan, K. A. (2000). An item response theory analysis of self-report measures of adult attachment. Journal of Personality and Social Psychology, 78, 350-365. doi: 10.1037/0022-3514.78.2.350

Güloğlu, B. ve Karaırmak, Ö. (2010) Üniversite öğrencilerinde yalnızlı̆̆ın yordayıcısı olarak benlik saygısı ve psikolojik sağlamlık. Ege Eğitim Dergisi, 11(2), 73-88.

Ha, J.Y. (2010). Drinking problems, stress, depression and self- esteem of university students. Korean Journal of Adult Nursing, 22(2), 182-189. 
Hamarta, E. (2004). Üniversite Öğrencilerinin Yakın İlişkilerindeki Bazı Değişkenlerin (Benlik Saygısı, Depresyon ve Saplantılı Düşünme) Bağlanma Stilleri Açısından İncelenmesi. (Yayınlanmamış Doktora Tezi). Selçuk Üniversitesi, Konya.

Hamidi, F. (2007). A study on the relationship between attachment styles and marital satisfaction in married students of teacher training university. Journal of familiy research, 3(9), 443-453.

Havighurst, R. J. (1972). Developmental tasks and education. David Mckay.

Hazan, C. ve Shaver, P. (1987). Romantic love conceptualized as an attachment process. Journal of Personality and Social Psychology, 52, 511-524. doi: 10.1037/00223514.52.3.511

Hoogstad, J. (2008). Choice theory and emotional dependency. International Journal of Reality Therapy, 28(1), 63-68.

Huntsinger, E. T. ve Luecken, L. J. (2004). Attachment relationships and health behavior: The mediational role of self-esteem. Psychology \& Health, 19(4), 515526. doi:10.1080/0887044042000196728

Isanejad, 0. ve Bagheri, A. (2018). Matiral quality, loneliness and Internet infidelity. Cyberpsychology, Behavior and Social Networking, 21(9), 542-548. doi: 10.1089/cyber.2017.0602

Kantarcı, D. (2009). Evli bireylerin bağlanma stillerine göre aldatma eğilimleri ve çatışma yönetim biçimlerinin incelenmesi. (Yayımlanmamış Yüksek Lisans Tezi). İstanbul Üniversitesi, İstanbul.

Karababa, A. (2021). Understanding the association betweem parental attachment and loneliness among adolescents: The mediating role of self- esteem. Curr Psychol. doi: 10.1007/s12144-021-01417-z.

Karabacak Çelik, A. ve Çiftçi, M. (2020). Evli bireylerin bağlanma stilleri ve psikolojik iyi oluşlarının evlilik uyumlarını yordayıcı rolü. Uluslararası Türkçe Edebiyat Kültür Eğitim Dergisi, 9(2), 898-918.

Karakurt, G. (2001). Yetişkin bağlanma stillerinin romantik kıskançlık üzerindeki etkileri (Yayımlanmamış Yüksek Lisans Tezi). Orta Doğu Teknik Üniversitesi, Ankara.

Karlıŏlu, B. ve Parlar, H. (2020). Evli bireylerde bağlanma stillerinin depresyon üzerindeki etkisinin incelenmesi. Sosyal Bilimler Araştırma Dergisi, 9(3), 180-187.

Kemer, G., Çetinkaya Yıldız, E. ve Bulgan, G. (2016). Emotional dependency and dysfunctional relationship beliefs as predictors of married Turkish individuals' relationship satisfaction. The Spanish Journal of Psychology, 19, E72. doi:10.1017/sjp.2016.78.

Kırıt Gülaydın, G. ve Semerci, B. (2018). Romantik ilişkisi olan yetişkin bireylerin ilişki doyumlarının bağlanma stilleri, benlik saygısı ve kişilerarası ilişki tarzları açısından incelenmesi. Psikoloji Araştırmaları, 3(6), 14-25. 
Levinson, D. J. (1986). A conception of adult development. American Psychologist, 41(1), 3-13.

Mustafa, S., Melonashi, E., Shkembi, F., Besimi, K. ve Fanaj, N. (2015). Anxiety and selfesteem among university students: Comparison between Albania and Kosovo. Procedia - Social and Behavioral Sciences, 205, 189-194.doi: 10.1016/j.sbspro.2015.09.057.

Odacı, H., Çıkrıkçı, Ö., Çıkrıkçı, N. ve Aydın, F. (2019). An exploration of the associations among cognitive flexibility, attachment styles and life satisfaction. International Journal of Happiness and Development, 5(3), 1-8. doi: 10.1504/IJHD.2019.103401.

Pallant, J. (2010). SPSS survival manual (4th ed.). New York, NY: McGrawHill.

Preacher, K. J. ve Hayes, A. F. (2004). SPSS and SAS procedures for estimating indirect effects in simple mediation models. Behavior Research Methods, Instruments, \& Computers, 36(4), 717-731. doi: 10.3758/BF03206553

Preacher, K. J., \& Hayes, A. F. (2008). Asymptotic and resampling strategies for assessing and comparing indirect effects in multiple mediator models. Behavior research methods, 40(3), 879-891. doi: 10.3758/BRM.40.3.879

Rogers, C. (1959). A theory of therapy, personality and interpersonal relationships as developed in the client-centered framework. In (ed.) S. Koch,Psychology: A Study of a Science. Vol. 3: Formulations of the Person and the Social Context. New York: McGraw Hill.

Rosenberg, M. (1965). Society and the adolescent self-image. Princeton, NJ: Princeton University Press.

Russell, D., Peplau, L. A. ve Ferguson, M. L. (1978). Developing a measure of loneliness. Journal of Personality Assessment, 42(3), 290-294. doi: 10.1207/s15327752jpa4203_11

Saadat, M., Ghasemzadeh, A. ve Soleimani, M. (2012). Self- esteem in Iranian university students and its relationship with academic achievement. Procedia- Social and Behavioral Sciences, 31, 10-14. doi:10.1016/j.sbspro.2011.12.007

Sarı, T. (2012). Evli bireylerin ebeveyn algıları, otomatik düşünceleri ve bağlanma stillerinin evlilik doyumu ile ilişkisi. (Yayımlanmamış Yüksek Lisans Tezi).Haliç Üniversitesi, İstanbul.

Sarı, T. ve Korkut Owen, F. (2016). Romantik İlişkilerde akılcı olmayan inançların ve bağlanma boyutlarının ilişki doyumu üzerindeki yordayıcı rolünün incelenmesi. Mehmet Akif Ersoy Üniversitesi Eğitim Fakültesi Dergisi, 1(37), 204-216.

Scantamburlo, G., Pitchot, W. ve Anseau, M. (2013). Affective dependency. Revue medicale de Liege, 68(5-6), 340-347. 
Scott, R. L. ve Cordova, J. V. (2002). The influence of adult attachment styles on the association between marital adjustment and depressive symptoms. Journal of Family Psychology, 16(2), 199-208. doi: 10.1037/0893-3200.16.2.199.

Selçuk,E., Günaydın, G., Sümer, N. ve Uysal, A. (2005). Yetişkin bağlanma boyutları için yeni bir ölçüm: Yakın ilişkilerde yaşantılar envanteri- II'nin Türk örnekleminde psikometrik açıdan değerlendirilmesi. Türk Psikoloji Yazıları, 8(16), 1-11.

Senchak, M. ve Leonard, K.E. (1992). Attachment styles and marital adjustment among newlywed couples. Journal of Social and Personal Relationships, 9(1), 51-64. doi: 10.1177/0265407592091003.

Simmons, B. L., Gooty, J., Nelson, D. L. ve Little, L. M. (2009). Secure attachment: Implications for hope, trust, burnout and performance. Journal of Organizational Behavior, 30(2), 233-247. doi: 10.1002/job.585

Stoliker, B.E. ve Lafreniere, K.D. (2015). The influence of perceived stress, loneliness, and learning burnout on university students' educational experience. Collage Student Journal, 49(1), 146-160.

Suri, S., Garg, S. ve Tholia, G. (2019). Attachment style, perceived social support and loneliness among college students. International Journal of Innovative Studies in Sociology and Humanities (IJISSH), 4(5), 135-142.

Sümer, N. (2006). Yetişkin bağlanma ölçeklerinin kategoriler ve boyutlar düzeyinde karşılaştırılması. Türk Psikoloji Dergisi, 21(57), 1-22.

Tabachnick, B. ve Fidell, L. (2013). Using multivariate statistics (6th ed.). Boston, MA: Pearson.

Taklavi, S. ve Ghodrati, S. (2019). Prediction of suicidal thoughts based on emotional failure and attachment styles among university students. Journal of Ardabil Unıversity of Medical Sciences, 19(2), 204-215.

Tepeli Temiz, Z. (2017). Üniversite öğrencilerinin bağlanma stilleri ile yaşam doyumu, psikolojik dayanıklık ve aleksitimik özellikleri arasındaki ilişkide benlik saygısının rolü. (Yayımlanmamış Yüksek Lisans Tezi). Fatih Sultan Mehmet Vakıf Üniversitesi, İstanbul.

Tepeli Temiz, Z. ve Tarı Cömert, I. (2018). The relationship between life satisfaction, attachment styles, and psychological resilience in university students. The Journal of Psychiatry and Neurological Sciences, 31, 274-283. doi: 10.5350/DAJPN2018310305.

Terzi, Ş. ve Cihangir Çankaya, Z. (2009). The predictive power of attachment styles on subjective well being and coping with stress of university students. Türk Psikolojik Danışma ve Rehberlik Dergisi, 4(31), 1-11.

Turanlı, P. (2010). Orta yetişkinlikte evlilik uyumu ile benlik saygısı ve bağlanma stilleri arasındaki ilişkinin saptanması. (Yayımlanmamış Yüksek Lisans Tezi). Maltepe Üniversitesi, İstanbul. 
Ünlü, F. (2015). Ebeveyni boşanmış bireylerde; benlik saygısı, yalnızlık ve bağlanma stilleri arasındaki ilişkinin incelenmesi. (Yayımlanmamış Yüksek Lisans Tezi). Haliç Üniversitesi, İstanbul.

Weiss, S. R. (1973). Loneliness: The experience of emotional and social isolation. New England: Typographical Service Inc.

Wiseman, H., Mayseless, O. ve Sharabany, R. (2006). Why are they lonely? Perceived quality of early relationships with parents, attachment, personality, predispositions and loneliness in first-year university students. Personality and Individual Differences, 40(2), 237-248. doi: 10.1016/j.paid.2005.05.015 
Bu çalışma için etik kurul izni 25/06/2021 tarih ve 2020/132 sayılı karar ile Düzce Üniversitesi Bilimsel Araştırma ve Yayın Etik Kurulu Başkanlığı'ndan alınmıştır.

\begin{tabular}{|l|}
\hline Araştırmacıların Makaleye Katkı Oranı Beyanı: \\
1. yazar katkı oranı: $\% 50$ \\
2. yazar katkı oranı: \%50 \\
\hline Çıkar Çatışması Beyanı: \\
Yok. \\
\hline Finansal Destek veya Teşekkür Beyanı \\
Bu çalıșma için herhangi bir kurumdan finansal destek alınmamıștır. \\
\hline
\end{tabular}

